[Vol. 130:1358

\title{
THE PUBLIC/PRIVATE DISTINCTION \\ IN LABOR LAW
}

\author{
KARL E. KLARE $†$
}

Legal discourse shapes our beliefs about the experiences and capacities of the human species, our conceptions of justice, freedom and fulfillment, and our visions of the future. It informs our beliefs about how people learn about and treat themselves and others, how we come to hold values, and how we might construct the institutions through which we govern ourselves. In these respects legal discourse resembles all other forms of systematized symbolic interaction. The peculiarity of legal discourse is that it tends to constrain the political imagination and to induce belief that our evolving social arrangements and institutions are just and rational, or at least inevitable, and therefore legitimate. The modus operandi of law as legitimating ideology is to make the historically contingent appear necessary. The function of legal discourse in our culture is to deny us access to new modes of conceiving of democratic self-governance, of our capacity for and the experience of freedom. Legal discourse inhibits the perception that we have it in our power to alter and abolish existing patterns of domination and denial of human potential. It is, in short, the vocation of legal thought to render radical, nonliberal visions of freedom literally inconceivable. ${ }^{1}$

The purpose of this Article is to illustrate and defend my claims regarding the ideological functions of legal discourse by focusing on the treatment of the public/private distinction in contemporary labor law. ${ }^{2}$ The field of labor law presents us with a

\section{Copyright $\odot 1982$ by Karl E. Klare}

† Professor of Law, Northeastern University; Visiting Faculty, Legal Services Institute, 1981-1982. B.A. 1967, Columbia University; M.A. 1968, Yale University; J.D. 1975, Harvard University. This Article owes much to the uniquely challenging and supportive environment of the Legal Services Institute, which I was privileged to have shared. I am solely responsible for whatever shortcomings the Article contains.

1 This is not to deny that legal discourse can also be a repository of emancipatory values and aspirations. See E.P. Thompson, Whugs and Hunters 258-69 (1975). See generally Thompson, The Moral Economy of the English Crowd in the Eighteenth Century, PAST \& Present, Feb. 1971, at 76 (arguing that rural food riots responded not merely to economic distress but also to a popular consensus that speculative grain marketing practices violated social and legal norms).

2 The phrase "public/private distinction" has several distinct connotations. For example, it is used to refer to the difference between "open" and "intimate"the key issue being "privacy." A second connotation is the difference between the 
rich lode to mine because public/private. rhetoric is pervasive in the adjudication of workplace disputes. The public/private distinction recurs not just as a background motif but very often as an essential ingredient of the grounds of decision. Indeed, courts and commentators often speak as though resolution of labor law problems would be impossible without a conceptual apparatus for distinguishing between public and private.

This is not surprising. The leading theorists of collective bargaining law have in large part based their work on an analogy between governance of the workplace and governance of society. ${ }^{3}$ This way of thinking has naturally inclined labor lawyers to import the vocabulary of constitutionalism into their work. Analogizing collective bargaining to lawmaking ${ }^{4}$ and treating collectively bargained plant operating procedures as an "industrial rule of law" 5 caused the reproduction within labor law of the categories, problems, and inflections of liberal theory. ${ }^{6}$ Conversely, as I have argued elsewhere, ${ }^{7}$ labor law registers the convergence in the liberal imagination of the politics of class struggle and the theory of the state.

world of work and government and the world of social life and family. This usage has been a focus of much attention in recent feminist writing, a key issue being sexism in the social division of labor. "Public/private" is also used to distinguish that which affects and concerns others and that which is "personal." Here the key issue is "regulation." The most important usage in labor law, and in the liberal political tradition generally, has to do with the distinction between the state and civil society. This is the sense in which the phrase is used throughout most of this Article.

${ }^{3}$ See generally Klare, Labor Law as Ideology: Toward a New Historiography of Collective Bargaining Law, 4 Indus. ReL. L.J. 450, 458-80 (1981); Lynd, Government Without Rights: The Labor Law Vision of Archibald Cox, 4 INDus. Rec. L.J. 483, 486-93 (1981); Stone, The Post-War Paradigm in American Labor Law, 90 YALE L.J. 1509, 1514-15, 1544-65, 1573-77 (1981).

4 See Cox, Some Aspects of the Labor Management Relations Act, 1947 (pt. 1), 61 HaRv. L. Rev. I, 1 (1947):

In annual conferences, the employer and the union representing the employees, in addition to fixing wage rates, write a basic statute for the government of an industry or plant .... By this "collective bargaining" the employee shares through his chosen representatives in fixing the conditions under which he works, and a rule of the law is substituted for absolute authority.

5 See id.; see also United Steelworkers v. Warrior \& Gulf Navigation Co., 363 U.S. 574, 579 (1960) (the collective bargaining agreement "calls into being a new common law-the common law of a particular industry or of a particular plant"); Shulman, Reason, Contract, and Law in Labor Relations, 68 HARv. L. REv. 999, 1002-16 (1955) (collective bargaining agreement establishes private rule of law in workplace).

${ }^{6}$ For a general description and criticism of the tradition of liberal political theory, particularly in relation to jurisprudential issues, see R. UNGER, KNowLEDGE AND PoLrTICs 63-103 (1975). For a discussion of the relationship of contemporary labor law to issues in liberal political thought, see Klare, supra note 3 , at 455-68.

i See generally Klare, supra note 3. 
A unique form of applied political theory, the philosophy of collective bargaining law has emerged since the 1930s as an important effort to conceptualize and justify government's regulatory role in advanced industrial society. For these reasons labor law provides a novel and promising setting in which to study the vagaries of preeminent liberal formulations like the public/private distinction.

For the most part the terms "public" and "private" will be used in this Article simply as they appear in the cases and doctrinal literature. However, these terms have several distinct if related and overlapping meanings, and this Article will be primarily concerned with the formulation that focuses on distinguishing between the "political" and "socio-economic" domains of life. ${ }^{8}$

Part I provides an overview of some specific doctrinal examples of the public/private distinction in labor law. Part II offers a more detailed examination of a particular problem, namely the various appearances of the public/private distinction in the theory of the collective bargaining and grievance processes. Parts I and II will attempt to establish that although public/private rhetoric is pervasive in labor doctrine, it is devoid of significant, determinate analytical content. Specifically, the Article will demonstrate the incoherence of the public/private distinction by showing that: (i) the distinct designations "public" and "private" are at different times, or even simultaneously, employed to characterize the same phenomena; ${ }^{9}$ (ii) judges and other legal thinkers beginning from an identical premise about the "publicness" or "privateness" of a particular phenomenon will arrive at sharply contrasting or opposed legal conclusions regarding it; or, beginning from opposed premises they will arrive at identical legal conclusions; ${ }^{10}$ and (iii) most important, the "borderline" dividing "public" and "private" is constantly being altered and redefined in the presence of new legal problems, but absent significant changes in the nature of the underlying phenomena or social forces that the labels "public" and "private" supposedly describe. ${ }^{11}$

\section{See supra note 2.}

${ }^{9}$ See, e.g., infra text accompanying notes 23-30 (authorities differ over whether arbitrators dispense public or private law); infra text accompanying notes 49-67 (authorities differ over whether unions are public or private entities).

${ }^{10}$ See, e.g., infra text accompanying notes 72-83 (same results in dues expenditure cases can be justified from each of two opposite initial positions on the public/private question).

11 See infra text accompanying notes 120-242 (history of arbitration in collective bargaining law reveals gradual evolution through which the employer's response to worker grievances shifted from the zone of private prerogative into the zone of public interest). 
Overall, the several examples contained in Part I and the extended review of one issue in Part II are intended to suggest that it is seriously mistaken to imagine that legal discourse or liberal political theory contains a core conception of the public/private distinction capable of being filled with determinate content or applied in a determinate manner to concrete cases. There is no "public/private distinction." What does exist is a series of ways of thinking about public and private that are constantly undergoing revision, reformulation, and refinement. The law contains a set of imageries and metaphors, more or less coherent, more or less prone to conscious manipulation, designed to organize judicial thinking according to recurrent, value-laden patterns. The public/private distinction poses as an analytical tool in labor law, but it functions more as a form of political rhetoric used to justify particular results.

Part III explores the apologetic character of public/private discourse in labor law, discussing three particular sets of political values that are contained in and reinforced by contemporary public/private rhetoric about the workplace. It argues that the use of such rhetoric obscures rather than illuminates, and that the social function of the public/private distinction is to repress aspirations for alternative political arrangements by predisposing us to regard comprehensive alternatives to the established order as absurd.

\section{The Pervasiveness of the Public/Private Distinction} IN LABOR LAW

The public/private distinction is a central category in many areas of labor doctrine. Contemporary legal thinkers are riveted to the idea that they can determine many rights and duties of the contending parties in the workplace by proper application of the labels "public" and "private." On the other hand, many existing and respected analyses of the workplace draw the public/private boundary line at different locations. Commentators share a comfortable and usually unexamined consensus that the public/private distinction is meaningful, that certain legal consequences must follow from designating a particular aspect of workplace life either "public" or "private." Yet the same thinkers frequently and markedly disagree over what the public/private distinction means and over which label is correct for many different aspects of the workplace. Moreover, it is a typical pattern that an author's analysis and arguments for classifying something as either "public" or "private" are promptly disregarded or forgotten, though they are equally germane, when the next item is under discussion. 
The easy consensus on the meaningfulness of the public/private distinction, coupled with total chaos regarding its application to specific instances, gives rise to the suspicion that the distinction is not an analytical tool but an after-the-fact rhetorical device used to justify political conclusions. Analysts seeking to expand employee rights vis-a-vis the employer generally do so by appealing to the public character of the subject under discussion, but the contortions of public/private analysis are sufficiently complex that this will not always be true. Few labor law analysts ever examine the conceptual validity of the public/private distinction itself. There is apparently a political value in clinging to the distinction, even if there is no common ground on what it means.

The following examples are primarily intended to convey a sense of the frequency, range, and ingenuity with which the distinction is deployed. They are presented in an order ranging from the more straightforward to the more complex. The discussion is not concerned with justifying or criticizing public intervention in particular cases. Rather, its purpose is to show the conceptual inadequacies and, ultimately, the ideological content of this way of thinking about workplace issues.

\section{A. Is the Employment Contract (in the "Private Sector") Affected with a Public Interest or Is It Simply a Private Relationship?}

At common law, the private sector employment contract is deemed an essentially private arrangement. A corollary of this view is that, absent explicit contrary contractual guarantees, employment may ordinarily be terminated at will for a good reason, a bad reason, or no reason at all.12 One of the most significant recent common law developments, however, is that several jurisdictions have begun to modify this rule by judicial decision. Either as a matter of tort or contract, a growing number of states now forbid the discharge of an employee at will for a reason that contravenes public policy. ${ }^{13}$ The result is that the private contract of employ-

12 See generally Blades, Employment at Will vs. Individual Freedom: On Limiting the Abusive Exercise of Employer Power, 67 Colvas. L. Rev. 1404 (1967); Feinman, The Development of the Employment at Will Rule, 20 AM. J. LEgaL Hiss. 118 (1976); Summers, Individual Protection Against Unjust Dismissal: Time for a Statute, 62 VA. I. REv. 481 (1976); Note, Implied Contract Rights to Job Security, 26 Stan. L. Rev. 335 (1974).

13 Leading cases include Tameny v. Atlantic Richfield Co., 27 Cal. 3d 167, 610 P.2d 1330, 164 Cal. Rptr. 839 (1980) (holding that when the discharge of an employee violates fundamental principles of public policy, the employee may maintain an action in tort; dismissal for refusal to participate in retail price-fixing 
ment is no longer deemed entirely private. Public law norms are implied into the relationship as restrictions upon the employer's power to discharge. ${ }^{14}$ This emergent trend illustrates the way that the boundaries of the public/private distinction are shifted without any relevant change in the underlying sociology of the employment relationship.

A curious counterpoint to this developing perception that the private employment relationship is affected with a public interest is found in the expansion and continuing vitality of the so-called "indefensible disloyalty" doctrine. While employees who engage in concerted workplace activity ordinarily can claim the protection of section 7 of the National Labor Relations Act (NLRA), ${ }^{15}$ under this doctrine employee concerted activity loses statutory protection if it is "indefensibly disloyal," "disruptive," or "irresponsible." 16

scheme); Sheets v. Teddy's Frosted Foods, Inc., 179 Conn. 471, 427 A.2d 385 (1980) (recognizing cause of action in tort for wrongful discharge where the discharge contravenes a clear mandate of public policy; retaliatory dismissal of employee who insisted that employer comply with state Food, Drug and Cosmetics Act); Harless v. First Nat'l Bank, 246 S.E.2d 270 (W. Va. 1978) (cause of action in tort for wrongful discharge; dismissal in retaliation for employee's efforts to have the bank comply with consumer credit protection laws); Fortune v. National Cash Register Co., 373 Mass. 96, 364 N.E.2d 1251 (1977) (unjust dismissal may constitute breach of implied covenant of good faith in employment contract; termination designed to prevent salesman from collecting earned bonuses); Monge v. Beebe Rubber Co., 114 N.H. 130, 316 A.2d 549 (1974) (holding that discharge for a reason that contravenes public policy is breach of implied covenant in employment contract; discharge of employee for refusing to accede to supervisor's sexual advances).

14 In all employment contracts, whether at will or for a definite term, the employer's interest in running his business as he sees fit must be balanced against the interest of the employee in maintaining his employment, and the public's interest in maintaining a proper balance between the two ..... We hold that a termination by the employer of a contract of employment at will which is motivated by bad faith or malice or based on retaliation is not [in] the best interest of the economic system or the public good and constitutes a breach of the employment contract.

Monge, 114 N.H. at 133, 316 A.2d at 551 (emphasis added).

This language could be read to imply that any bad faith termination contravenes the public good. Alternatively, it could be interpreted to mean that in order to show a breach of the implied contractual covenant of good faith, the employee must show that the dismissal was for a reason that contravenes public policy. This ambiguity was subsequently resolved in favor of the latter interpretation. Howard v. Dorr Woolen Co., 120 N.H. 295, 297, 414 A.2d 1273, 1274 (1980) ("We construe Monge to apply only to a situation where an employee is discharged because he performed an act that public policy would encourage, or refused to do that which public policy would condemn."). See also Cloutier v. Great Atl. \& Pac. Tea Co., 121 N.H. 915, 920, 436 A.2d 1140, 1143 (1981) (Dorr Woolen limited Monge to cases involving dismissals for reasons that contravene public policy).

1529 U.S.C. $\$ 157$ (1976) ("[e]mployees shall have the right . . . to engage in . . . concerted activities for the purpose of collective bargaining or other mutual aid or protection").

10 The leading case is NLRB v. Local 1229, Int'l Bhd. of Elec. Workers, 346 U.S. 464 (1953). For recent discussions, see, e.g., Pacemaker Yacht Co. v. NLRB, 
The curious twist is that in the context of the heavily regulated collective bargaining relationship, as to which the public's interest is well established, ${ }^{17}$ decisionmakers have substantially relied on private law norms to interpret the public regulatory scheme, diluting statutory guarantees.

The leading case in this area involved employees who, in the course of a labor dispute with a publicly licensed TV station, chose to center their propaganda on alleged deficiencies in their employer's service to the public rather than on their private, employment-related claims. ${ }^{18}$ The quality of a public licensee's service is, of course, a matter in the public domain. As citizens and as members of the "public," these employees had an unquestioned right to discuss the station's service and, indeed, to attack the "public policies of the company." 19 As employees, however, they were not acting as members of the public but rather in a private capacity, subject always to "contractual bonds and loyalties" 20 to the employer. The Supreme Court found that the private law rule that "disloyalty is adequate cause for discharge" 21 provides a sufficient basis to extinguish the public law employee right to engage in concerted activity. Likewise, the Court concluded that disparagement of the employer's product-even by way of truthful criticism or by way of opinion designed to assist the public in assessing the performance of its licensee-is an act of disloyalty warranting discharge. ${ }^{22}$

663 F.2d 455, 462-63 (3d Cir. 1981) (Garth, J., concurring); G.T.A. Enters., Inc., 260 N.L.R.B. No. 29 (1982). This doctrine is patently incoherent. The very purpose of some conventional forms of concerted workplace protest, like strikes, is to disrupt the employer's business. Most forms of concerted activity can be said to constitute acts of disloyalty toward the policies of the employer. In practice the doctrine singles out for condemnation certain forms of worker protest not because they are especially disloyal or indefensible, but because they are unusually effective. See, e.g., Cox, The Right to Engage in Concerted Activities, 26 IND. L.J. $319,338-39$ (1951) (slowdowns and similar tactics unprotected by NLRA because "such weapons are too effective to permit them to be part of the employees" arsenal").

1729 U.S.C. $\$ 151$ (1976) ("[i]t is declared to be the policy of the United States to ... encourag[e] the practice and procedure of collective bargaining and [to protect] the exercise by workers of full freedom of association [and] self-organization").

18 Local 1229, Int'l Bhd. of Elec. Workers, 346 U.S. at 467-77.

$19 \mathrm{Id} .476$.

$20 I d .473$.

21 Id. 475.

22 Id. 477. Cf. Patterson-Sargent Co., 115 N.L.R.B. 1627, 1629 (1956) ("Is]tatements made by employees to the public which deliberately cast discredit upon their employer's product or service are no less disloyal and a breach of confidence because they are truthful"). 


\section{B. Do Labor Arbitrators Dispense "Public Law" or "Private Law"?}

This is a perennial and hotly debated issue in the labor field. A typical form of the debate revolves around the question whether arbitrators may, should, or must resolve grievances in light of legal norms "external" to the parties' contract, that is, in light of public law rules such as the equal employment provisions of the Civil Rights Act of $1964 .{ }^{23}$ Opinion on this question ranges across a very broad spectrum: ${ }^{24}$

(1) Professor Feller's view is that the arbitrator should never follow rules derived from law external to the collective bargaining agreement (in the event of conflict between public law and contractual norms). He believes that the arbitrator performs within and is responsible to an autonomous system of industrial selfgovernment and private law established by labor and management. ${ }^{25}$ From this perspective it follows that the arbitral system performs an indispensable role in the public management of industrial conflict. Feller concludes, therefore, that as a matter of public law arbitral decisions administering the parties' private law system should be granted a special deference by the courts, akin to the full faith and credit owed the judgments of foreign jurisdictions. ${ }^{20}$

(2) A related but somewhat different perspective is Professor St. Antoine's view that the arbitrator is merely the parties' official "contract reader." For that reason, St. Antoine argues, arbitrators should follow the contract despite a conflict with public law.27 $\mathrm{He}$ concludes, however, that because the arbitrator's role is to fill out the parties' agreement, arbitral awards are not entitled to any formal judicial deference regarding the lawfulness of the conduct they

23 Title VII of the Civil Rights Act of 1964, $\$ \S 701-718,42$ U.S.C. $\$ \$ 2000 \mathrm{e}$ to $2000 \mathrm{e}-17$ ( 1976 \& Supp. IV 1980). Title VII prohibits employment discrimination on the basis of race, color, religion, sex, or national origin. Id. $\$ 2000 \mathrm{e}-2$.

24 The debate over the status of arbitral law illustrates the stage in the history of legal thought Professor Kennedy calls "continuumization." Kennedy, The Stages of the Decline of the Public/Private Distinction, 130 U. PA. L. REv. 1349, 1352 (1982).

25 See generally Feller, The Coming End of Arbitration's Golden Age, 29 NAT'L ACAD. ARB. 97 (1976); id. 107 ("the very special status that courts have awarded arbitrators ... derives from a ... recognition that arbitration is not a substitute for judicial adjudication, but a part of a system of industrial self-governance").

26 Feller, supra note 25, at 107.

27 St. Antoine, Judicial Review of Labor Arbitration Awards: A Second Look at Enterprise Wheel and Its Progeny, 75 Mrcr. L. Rev. 1137, 1138-44 (1977); cf. id. 1155 ("an arbitrator confronted with an irreconcilable conflict between the terms of a collective bargaining agreement and the apparent requirements of statutory or decisional law should follow the contract and ignore the law"). 
command. ${ }^{28}$ Thus, while both Feller and St. Antoine agree that the arbitrator fills out a system of private law, they reach opposite conclusions as to whether that private law system performs a sufficiently significant public function so as to earn the status of a species of public law to which courts must defer.

(3) Moving to the middle of the spectrum, we find many commentators who, for different reasons and with varying degrees of enthusiasm, call for explicit arbitral responsiveness to the commands of public law. ${ }^{29}$ Implicit in these middle-range positions is the assumption that arbitral law is woven into the fabric of a general system of law governing the workplace.

(4) Finally there is an extreme position, seriously proposed although not reached for decision by Judge Lumbard in a leading case: the view "that since the arbitrator is an instrument of national labor policy, he is not a mere 'private' person, but rather one acting on behalf of the government who must take into account [employees' constitutional] rights." ${ }^{30}$ The logic of this view is to break down entirely the distinction between public and private law and to regard private arbitrators as governmental officials.

\section{Is the (Private Sector) Workplace a "Public" or a "Private" Place?}

This area provides a classic illustration of the inconsistent application of the labels "public" and "private." Discussion of the public or private character of the workplace often turns on the question of ownership, ${ }^{31}$ and the typical assumption is that the

28 Id. 1150 ("when a court declines to enforce an arbitral award that violates law or public policy, it does not question the veracity of the arbitrator's reading of the contract; it rules that the contract as read is unenforceable"); cf. id. 1150-61.

${ }^{29} \mathrm{See}$, e.g., Getman, What Price Employment? Arbitration, The Constitution, and Personal Freedom, 29 NAx'L ACAD. ARB. 61 (1976); Howlett, The Arbitrator, the NLRB, and the Courts, 20 NAT'I ACAD. ARB. 67 (1967); Mittenthal, The Role of Law in Arbitration, 21 NAT'L ACAD. ARB. 42 (1968); Sovern, When Should Arbitrators Follow Federal Law?, 23 NAT'L ACAD. ARB. 29 (1970).

30 Holodnak v. Avco Corp., 381 F. Supp. 191, 204 n.12 (D. Conn. 1974), modified, 514 F.2d 285 (2d Cir.), cert. denied, 423 U.S. 892 (1975).

31 It is often assumed that determinate, specifiable consequences flow from the demarcation between public and private ownership, but this is plainly false. Consider, for example, the legal treatment of parks and thoroughfares. The modern view is that if they are publicly owned, the first amendment prevents regulation of speech thereon except in narrow circumstances and then only on a content-neutral basis. See L. Trube, American Constixutional Law 688-93 (1978). On the other hand, a private owner of such spaces is, with certain exceptions, privileged to exclude speech on any basis, including its content, or on no basis. See Hudgens v. NLRB, 424 U.S. 507 (1976). Until relatively recently, however, the view was that government had the prerogatives of a private owner and therefore could exclude expressional activity in public places. See, e.g., Commonwealth v. Davis, 
private sector workplace is the property of the employer. ${ }^{32}$ Although employees heavily invest their "human capital" in the enterprise for which they work, they do not thereby ordinarily acquire any "property interest" in it..33 Modern legal scholarship, however, demonstrates that the concept of "private property" is really an emblem for "the conclusion that certain patterns of behavior are to be enforced between people for the benefit of society as a whole." ${ }^{34}$ Even a partial survey of the conventional indicia of property. ownership suggests that the patterns of behavior enforced by law in the workplace are ambiguous, contradictory, and riddled with exceptions. This casts doubt upon the simplistic assumption that the employer owns the workplace.

\section{Power to Exclude}

One of the bundle of rights usually thought to be associated with private property ownership is the power to exclude unwanted visitors and activities. The employer's power to exclude in the private sector workplace, however, is subject to substantial exceptions. The NLRA recognizes a public interest in permitting onpremises leafletting through which workers can educate each other on matters of mutual concern, including matters in the public domain outside the scope of the private employment relationship. ${ }^{35}$

162 Mass. 510, 511 (1895) (Holmes, J.) (for government "absolutely or conditionally to forbid public speaking in a highway or public park is no more an infringement of the rights of a member of the public than for the owner of a private house to forbid it in his house"), aff'd sub nom. Davis v. Massachusetts, 167 U.S. 43 (1897). See generally Kairys, Freedom of Speech, in THE Pourrics of LAW 140, 142-44 (Kairys ed. 1982); Rosenblatt, Legal Entitlement and Welfare Benefits, in Tre Politics of LAw, supra, at 262, 265-68.

$32 \mathrm{I}$ assume for purposes of discussion that there is some meaningful sense in which to speak of corporate property as "private property." Professor Frug has demonstrated that "developments in the twentieth century have significantly undermined the 'privateness' of major business corporations, with the result that the traditional bases for distinguishing them from public corporations have largely disappeared." Frug, The City as a Legal Concept, 93 HARv. L. REv. 1057, 1129 (1980); see also id. 1128-41.

33 See, e.g., United Steel Workers, Local No. 1330 v. United States Steel Corp., 492 F. Supp. 1, 9-10 (N.D. Ohio), affd in part and vacated and remanded in part, 631 F.2d 1264 (6th Cir. 1980) (neither employees nor local community have a property right in steel plant sufficient to bar plant closedown).

34 Comment, Unemployment As A Taking Without Compensation, 43 S. CaL. L. Rev. 488, 490 (1970). See also Cohen, Dialogue on Private Property, 9 Rutgens L. REv. 357, 373-74 (1954) (private property defined as certain patterns of human interaction underwritten by public power); Hamilton, Property-According to Locke, 41 YALE L.J. 864, 879 (1932) (property "is but a name for a cluster of prevailing usages ... which binds the individual to the social order").

35 See Eastex, Inc. v. NLRB, 437 U.S. 556 (1976) (employees may distribute union leaflets discussing both collective bargaining and general political matters on employer's premises). The source of this right is $\$ 7$ of the NLRA. The public 
We could think of this public interest as creating an easement for the purpose of protected leafletting on the property of the employer, but it makes equal sense to say that the employer's and the public's rights in the property are defined so as to include expressional access. ${ }^{36}$ Employees are thus statutorily guaranteed the right to engage in certain forms of on-premises leafletting and other communication (for example, wearing union buttons). ${ }^{37}$ To this extent employers are forbidden to deploy their authority and power as owners to interfere with the use of the workplace for the conduct of such activity. ${ }^{38}$ The law recognizes that the workplace is uniquely suited to communicative interaction between employees, that it is

interest in guaranteeing expressional access may not extend to mutual education of workers on "purely political" matters, overly "remote" from the interests of employees as employees. Id. 567-68. That is, the public interest in on-premises worker education is circumscribed by the horizons of private self-interest; it is not so expansive as to encompass the entirety of concerns reposing in the public domain. By "employee as employee" the law evidently means something less than employee as citizen or community-member. See supra text accompanying notes 15-22. See generally K. MARx, On the Jewish Question, in EARLY WRTTINGS 211 (R. Livingstone \& G. Benton trans. 1975) (social and institutional life in capitalist society fractures the personality between bourgeois and citoyen).

36 Indeed, at one point certain private workplaces, notably shopping centers, were deemed akin to "public places ... historically associated with the exercise of First Amendment rights." Amalgamated Food Employees Union v. Logan Valley Plaza, Inc., 391 U.S. 308, 315 (1968). See generally id. 315-20. Logan Valley was overruled by Hudgens v. NLRB, 424 U.S. 507 (1976). Hudgens seemingly leaves open whether certain locations other than shopping centers may, even though privately owned, so closely resemble public space historically dedicated to first amendment expression that use of such locations is governed by the Constitution. A number of state courts have relied on free speech provisions in their own state constitutions to enforce a public right of access to certain kinds of private property, including shopping centers. See, e.g., Robins v. Pruneyard Shopping Center, 23 Cal. 3d 899, 592 P.2d 341, 152 Cal. Rptr. 854 (1979), aff d, 447 U.S. 74 (1980) (shopping center); State v. Schmid, 84 N.J. 535, 423 A.2d 615 (1980), appeal dismissed sub nom. Princeton Univ. v. Schmid, 102 S. Ct. 867 (1982) (private university campus).

37 The primary source of employee leafletting and solicitation rights is $\$ 7$ of the NLRA. See generally R. Gorman, Basic Text on Labor Law 179-94 (1976).

38 In special circumstances the $\$ 7$ right of access to the employer's property, and the consequent limitation on the employer's power to exclude, extends to nonemployees (such as professional union organizers). R. Gorman, supra note 37, at $185-87$.

Under prevailing doctrine, the NLRB is required to "strike a balance between the interests of the employer-which are not specifically accorded weight in the statute but which Congress surely intended be considered in administering a statute designed to further industrial peace and efficiency-and the interests of employees in a free decision concerning their collective bargaining activities." Id. 133. This doctrine undermines the goals of the statute. Under a preferable approach the Board would give meaning to $\$ 7$ by determining an optimal level of organizational activity in the workplace consistent with the statute's goals and without respect to whether contrary employer interests are infringed. 
their natural forum for job-related and other forms of public expression. ${ }^{39}$

\section{Rights of Privacy ${ }^{40}$}

The traditional view is that the institution of private property is a shield against public power which, among other things, can create for the owner the benefits of a physical and psychological zone of privacy. In what may be an exquisite example of Professor Kennedy's "loopification," 41 however, workers now look to public power for protection of their privacy rights from the institution of private property. There is increasing support for the proposition that the public has an interest worthy of legal recognition in creating zones of privacy for employees on the employer's private property and within the employment relationship. For example, many states have statutes regulating the collection, use, and disclosure by employers of personal information on employees. ${ }^{42}$ Similarly, arbitral authority supports employees' rights to privacy in their lockers and handbags, as well as on their persons. ${ }^{43}$

\section{Uses of the Private Workplace}

Private property is ordinarily viewed as an instrument of private ends, yet the workplace is also sometimes deemed a preeminent

39 Cf. Gale Prod. Div. of Outboard Marine Corp., 142 N.L.R.B. 1246, 1249 (1963), enforcement denied, 337 F.2d 390 (7th Cir. 1964):

Their place of work is the one location where employees are brought together on a daily basis. It is the one place where they clearly share common interests and where they traditionally seek to persuade fellow workers in matters affecting their union organizational life and other matters related to their status as employees.

This passage is quoted with approval in Eastex, 437 U.S. at 574, and NLRB v. Magnavox Co., 415 U.S. 322, 323-24 (1974).

40 In addition to the types of privacy rights discussed in this paragraph, the concept of privacy has also been seen as the source of rights to free choice in the workplace regarding the development and expression of one's personality. An example is the derivation from constitutional privacy doctrine of a principle of nondiscrimination in public employment on account of sexual preference. See infra text accompanying notes 119-27.

41 Kennedy, supra note 24, at 1354.

42 A recent Bureau of National Affairs survey discloses that 33 states have such Iaws. Legislation on Workers' Privacy, 109 LAB. Rer. RPtr. (BNA) 8-13 (Jan. 4, 1982).

43 See F. Elkouri \& E. Elkouru, How Arbitration Works 727-33 (3d ed. 1973): In a similar vein, 17 states and the District of Columbia prohibit employers from requiring employees or prospective employees to submit to a lie detector test as a condition of obtaining or retaining employment. Legislation on Workers' Privacy, supra note 42, at 11-12. See also Perks v. Firestone Tire \& Rubber Co., 611 F.2d 1363 (3d Cir. 1979) (discharge of employee at will for refusal to submit to polygraph examination gives rise to tort action for wrongful discharge). 
instrumentality for accomplishing the goals of public policy, such as economic planning. For example, recently Detroit condemned the homes and neighborhood of elderly workers and donated the property to the General Motors Corporation for construction of a new plant. The city's purpose was to alleviate unemployment and fiscal distress. The Supreme Court of Michigan held, as it was required to do in order to validate the transaction, that the condemnation was "for the primary benefit of the public [not that of] the private user." 44

We know, then, that a large corporate employer like General Motors exists by virtue of public law; it is heavily subsidized by the public; it is a prime instrument of public policy and planning; it is entangled in countless ways in public regulatory schemes; it has the power to tax the public by charging administered prices sheltered by tepid interpretations of the antitrust laws; its space is open to use by others to promote collective bargaining and other ideological causes to which GM might be deeply opposed; government purchasing puts money in its coffers; it uses the mass media to mold the public's tastes and "preferences"; and its every whim is Detroit's desire.

Curiously, the law persists in treating such an entity as "private." Thus, to protect the employer's "privacy interests" the Occupational Safety and Health Administration must have a search warrant to conduct routine, prophylactic safety inspections that might save the lives or limbs of workers who pass their days upon the employer's private commercial property. ${ }^{45}$ The employer is permitted to treat off-duty employees as though they were nonemployee strangers in administering the rules regarding access to premises, ${ }^{46}$ a doctrine that undermines the recognition of the workplace as the natural forum for communication between workers. The employer's authority to manage the work process and to make investment decisions falls within a tenaciously protected realm of private prerogative, one largely exempted from the inroads of collective

44 Poletown Neighborhood Council v. City of Detroit, 410 Mich. 616, 617, 304 N.W.2d 455, 459 (1981) (emphasis added). In a remarkable passage, citing an earlier dictum of Justice Cooley, the court stated: "When there is [a] public need [which is otherwise impracticable], [t] he abstract right [of an individual] to make use of his own property in his own way is compelled to yield to the general comfort and protection of community, and to proper regard to relative rights in others." Id. 459 (citation omitted).

45 See Marshall v. Barlow's, Inc., 436 U.S. 307 (1978).

46 See Tri-County Medical Center, 222 N.L.R.B. 1089 (1976); GTE Lenkurt, Inc., 204 N.L.R.B. 921 (1973). 
bargaining law. ${ }^{47}$ American law recognizes no property interest of employees or of the surrounding community in the disposition of the employer's capital. 48

Thus, while in many aspects we acknowledge the public character of the workplace, particularly when we come to questions involving the allocation of resources the "privateness", of the workplace is reasserted. Despite overwhelming evidence to the contrary, the idea that the workplace is a "private place," is "private property," endures as a powerful cultural underpinning of the sovereignty of capital.

\section{Is a Labor Union a "Public" or "Private" Entity? 49}

This question has many doctrinal formulations, such as whether various actions of labor unions constitute "governmental action" for constitutional purposes. ${ }^{50}$ Another formulation will serve as the focus of this section: whether a union has the traditional prerogative of a private voluntary association to determine eligibility to its own membership.

Mitchell v. International Association of Machinists is a leading although dated case illustrating the problem. In Mitchell, a California court held unlawful a union's expulsion of a member for publicly advocating a right-to-work initiative, even though it found that the union reasonably deemed the initiative a "serious threat" to its welfare and existence. ${ }^{51}$ The court reasoned that labor unions are not purely private, voluntary associations as contrasted with such organizations as the Republican and Democratic parties.

47 See Fibreboard Paper Prod. Corp. v. NLRB, 379 U.S. 203, 223 (1964) (Stewart, J., concurring) (no duty "to bargain collectively regarding . . . managerial decisions ... which lie at the core of entrepreneurial control").

48 See supra note 33 and accompanying text. But see City of Oakland v. Oakland Raiders, 646 P.2d 835, 183 Cal. Rptr. 673 (1982) (city invokes power of eminent domain to prevent departure of major enterprise; court reverses summary judgment for defendant and remands for determination whether condemnation is for valid public use).

49 Aspects of this problem are explored in Klare, supra note 3, at 470-73.

50 Compare, e.g., United Steelworkers v. Sadlowski, 102 S. Ct. 2339, 2350 n.16 (1982) (Marshall, J.) (rejecting claim that union's adoption of ban on nonmember contributions in union elections constitutes governmental action) with Steele v. Louisville \& N.R.R., 323 U.S. 192, 198-203 (1944) (duties imposed on unions by virtue of their quasi-governmental status vis-a-vis represented employees). Thurgood Marshall appeared in Steele as counsel for the National Association for the Advancement of Colored People. His amicus curiae brief forcefully advanced the view that collective bargaining institutions have a governmental character as to which constitutional norms ought to be applied. See Motion and Brief for Amicus Curiae National Association for the Advancement of Colored People at 27-31, Steele. 51 Mitchell v. International Ass'n of Machinists, 196 Cal. App. 2d 796, 806, 16 Cal. Rptr. 813, 819 (1961). 
Rather, by virtue of their power, function, and legal authority they are quasi-public entities. Accordingly, unions are subject to a higher degree of public regulation than would be tolerable vis-a-vis an ordinary private organization. On this basis, the court found that the public has an interest in compelling unions to allow dissenters to carry on debate within the union regarding controversial matters of public concern. ${ }^{52}$ The referendum on compulsory unionism was found to be such a topic, and the expelled member was held entitled by law to reinstatement to membership. ${ }^{53}$ Mitchell thus lends support to the proposition that the union hall is a public forum.

What about the question of race discrimination in union membership policies? Prior to title VII of the 1964 Civil Rights Act, ${ }^{54}$ the law in most jurisdictions tolerated union race discrimination on the theory that unions are private, voluntary associations free to establish their own rules for membership eligibility, ${ }^{55}$ a theory endorsed by the United States Supreme Court. ${ }^{56}$ Surely,

52 See id. at 801 n.3, 16 Cal. Rptr. at 816 n.3. It is important to note that the issue in a political expulsion case is not whether the member has a general right to advocate his or her views on controversial subjects. The first amendment already protects such advocacy, and NLRA $\$ 8(a)(3),(b)(2), 29$ U.S.C. $\$ 158(a)(3)$, (b) (2) (1976), protect job rights from employer and/or union retaliation against employees because they are out of favor with the union. See NLRB v. General Motors Corp., 373 U.S. 734, 742 (1963) (union membership and allegiance are "whittled down to [their] financial core" as far as authorized union security devices are concerned). The issue in political expulsion cases is whether the employee has a right to advocate minority views and at the same time to insist upon being a union member: to work against the union's collectively defined interests and yet to be accepted by it. Perhaps the answer to these questions should be the same, but they are different questions, and pose different problems.

53 The history of the legal treatment of expulsion of communists from union membership provides an ironic twist on this point. Initially, exclusion of communists from unions was justified on the ground that unions, by virtue of their governmentally derived powers (i.e., by virtue of their semipublic status), had corresponding responsibilities to protect the public from the imagined threat of communist subversion. The leading case is American Communications Ass'n v. Douds, 339 U.S. 382 (1950). In more recent times, the premise that unions are semipublic entities answerable to public law norms is a basis for the conclusion that communists may not be excluded from unions. See, e.g., Turner v. Air Transp. Lodge 1894, Int'l Ass'n of Machinists, 590 F.2d 409 (2d Cir. 1978), cert. denied, 442 U.S. 919 (1979).

5442 U.S.C. $\$ \$ 2000$ e to $2000 \mathrm{e}-17$ (1976 \& Supp. IV 1980).

55 The leading case was Oliphant v. Brotherhood of Locomotive Firemen, 262 F.2d 359 (6th Cir. 1958), cert. denied, 359 U.S. 935 (1959). Note, however, that NLRA $\$ 8(a)(3),(b)(2), 29$ U.S.C. $\$ 158(a)(3),(b)(2)$ (1976), and the common law of some states, including California, e.g., James v. Marinship Corp., 25 Cal. 2d 72I, 155 P.2d 329 (1944), condemned race discrimination in union membership when unions sought to enforce union security agreements. See infra text accompanying note 70 .

56 Steele, 323 U.S. at 204 (1944) (collective bargaining laws do not deny a bargaining representative "the right to determine eligibility to its membership"). 
however, the California court that decided Mitchell spoke of the public interest in ensuring diversity in union membership in terms so sweeping as to mandate an end to racial exclusion? Regrettably not. The Mitchell court distinguished the question of racial exclusion as one that does not pose a problem as to which the public's interest is strong enough to outweigh the union's traditional prerogatives as a private organization. ${ }^{\mathbf{5 7}}$ Although unions were more "public" than the Democratic party-which had long before been compelled to drop the race bar ${ }^{58}$-labor unions were apparently still not "public" enough for this court to declare their Jim Crow practices illegal.

The 1964 Civil Rights Act has of course made clear that labor unions are forbidden to engage in race or other invidious discrimination. ${ }^{50}$ In other areas, however, enormous confusion remains as to the legal status of labor unions. For the most part unions are still treated as private voluntary associations. Yet the law imposes a degree of supervision over internal union affairs that appears quite incompatible with "private" status. ${ }^{60}$ These statutory controls are justified on the ground that the public has a vital interest in encouraging responsible leadership and democratic governance in unions. ${ }^{61}$ Curiously, however, the courts will decide in particular

Steele is discussed at length in Klare, The Quest for Industrial Democracy and the Struggle Against Racism: Perspectives from Labor Law and Civil Rights Law, 61 OR. L. REv. 157, 185-98 (1982).

57196 Cal. App. 2d at 807, $16 \mathrm{Cal}$. Rptr. at 820.

58 See Terry v. Adams, 345 U.S. 461 (1953); Smith v. Allwright, 321 U.S. 649 (1944); Nixon v. Condon, 286 U.S. 73 (1932); Nixon v. Herndon, 273 U.S. 536 (1927) (the White Primary Cases). See generally L. Truse, supra note 31 , at $787-90$.

6942 U.S.C. $\$ 2000 \mathrm{e}-2$ (c) (1976) (making unlawful union exclusion, expulsion, or other discrimination on basis of race, color, religion, sex or national origin).

${ }^{60}$ The primary vehicles of legal supervision of internal union affairs are:

(a) the Labor-Management Reporting and Disclosure (Landrum-Griffin) Act of 1959, Pub. L. No. 86-257, 73 Stat. 519 (codified at 29 U.S.C. $\$ \$ 401-531$ (1976) and other scattered sections of 29 U.S.C.) (LMRDA);

(b) the cause of action for the breach of the duty of fair representation implied from $\S 2$, Fourth of the Railway Labor Act, 45 U.S.C. $\$ 152$, Fourth (1976), see Steele v. Louisville \& N.R.R. Co., 323 U.S. 192 (1944), and from NLRA §9(a), 29 U.S.C. $\$ 159$ (a) (1976), see Ford Motor Co. v. Huffman, 345 U.S. 330, 336-38 (1953); and

(c) to a somewhat lesser extent, NLRA $\$ 8(\mathrm{~b})(\mathrm{I})(\mathrm{A}), 29$ U.S.C. $\$ 158$ (b)(1)(A) (1976).

The vast subject of legal regulation of internal union affairs is obviously beyond the scope of this Article, but it is fair to say that such regulation is sweeping and raises serious questions as to the meaningfulness of designating unions "private" associations. It is doubtful that such regulation of internal operating procedures would be tolerated if applied to business corporations.

61 See LMRDA $\$ 2,29$ U.S.C. $\$ 401$ (1976) (congressional finding that public interest in protecting employees and the free flow of commerce requires federal supervision of the behavior and governance of labor unions). 
contexts to narrow the scope of their supervisory authority over unions. Yet rather than articulate a political rationale for such abstention, the courts characteristically revert to the general notion that intervention is illicit because labor unions are private entities, whose duly constituted "management" is entitled to judicial deference. ${ }^{62}$ With some regularity, for example, the public/private distinction has been invoked as a barrier to those who seek to foster union democracy by means of litigation. ${ }^{63}$

62 For example, in the 1960 's judicial intervention to protect the "due process" rights of union members guaranteed by LMRDA $\$ 101(\mathrm{a})(5), 29$ U.S.C. $\$ 411$ (a) (5) (1976), was fairly substantial. See, e.g., Falcone v. Dantinne, 420 F.2d 1157 (3d Cir. 1969); International Bhd. of Boilermakers v. Braswell, 388 F.2d 193 (5th Cir.), cert. denied, 391 U.S. 935 (1968); Vars v. International Bhd. of Boilermakers, 320 F.2d 576 (2d Cir. 1963). This trend was then inhibited by the Supreme Court's decision in International Bhd. of Boilermakers v. Hardeman, 401 U.S. 233 (1971). The Court established a deferential standard of judicial review of union disciplinary proceedings, id. 246 , in large part based on the view that unions ought to be left "to govern their own affairs." Id. Justice Douglas' dissent took the opposite tack. He urged a highly interventionist posture, under which union disciplinary proceedings would be held to constitutional standards. Id. 252-53. In support of this view, he assumed that unions are not private organizations but are in essence empowered by and responsible to the public. Id. 251-52 ("it is unthinkable to me that Congress . . . gave unions the authority to expel members for such reasons as they chose"). See also Newman v. Local 1011, Communications Workers, $570 \mathrm{~F} .2 \mathrm{~d}$ 439, 445-46 (2d Cir. 1978) (regarding removal of militant shop steward, in absence of very substantial showing of purpose to suppress dissent, courts will defer to actions of union officers out of adherence to "longstanding policy against intervention in the internal affairs of unions").

63 Thus, for example, Ed James argues that administrative and judicial interpretation of the union election provisions of title IV of the LMRDA, 29 U.S.C. $\$ \$ 481-483$ (1976), have rendered the Act ineffective in fulfilling its promise to guarantee internal union democracy with respect to insurgent electoral challenges and turnover of incumbent leadership. James, Union Democracy and the LMRDA: Autocracy and Insurgency in National Union Elections, 13 HaRv. C.R.-C.L. L. REv. $247,248-50,266,270-325$ (1978). One of the reasons behind this failure is the tendency of courts to invoke the "privateness" of unions to justify a noninterventionist posture, despite the highly intrusive character of the statutory scheme and premises:

Why, then have title IV courts been reluctant to fashion more effective relief? Some of the reluctance may stem from the feeling that unions are voluntary associations and that their internal affairs should be their own business. However, in enacting the LMRDA, Congress opted for the enforcement of union democracy over claims of union autonomy.

Id. 323 (citations omitted). Cf. id. 308 ("Judicial supervision [of the union election process] has been characterized by the twin themes of deference to the [Labor] Secretary's expertise and a policy against intrusion into the internal affairs of unions.").

There may well be good arguments against the effort to enforce principles of union democracy through judicial intervention, and good arguments in favor of union autonomy and notions of informal justice. Friends of the labor movement earnestly debate the proper role of law in enhancing union democracy. The point here is that such arguments ought to be explicitly articulated and overtly grounded in a political vision of the labor movement. Stereotyped arguments resting on manipulation of the public/private distinction are no substitute for much needed political analysis of these questions. 
An important recent case, Wade v. Teamsters, Local $247,{ }^{64}$ illustrates the "flip-flop" character of judicial oscillation on the question of union status. Wade holds that a local union's failure to conduct regular monthly membership meetings violates union members' participation rights embodied in title I of the LMRDA. The court ordered the union to hold such meetings pursuant to judicially established guidelines. ${ }^{65}$ This holding and remedial provision are extraordinarily interventionist. Yet the very same court declined to rule that the union's refusal to convene a meeting to consider certain bylaw amendments proposed by the rank-and-file is actionable as a breach of the "contract" between the union and its members. The reasoning offered to support this result was that Congress intended that "judicial intrusions into internal union affairs should be limited." "6s The central contradiction in the court's approach-indeed, in this entire area of the law-is dramatically illustrated by a passage in the discussion of remedies wherein the court, in effect, orders the union to hold meetings of the type normally held by voluntary associations. ${ }^{67}$

\section{E. Do Labor Unions Perform a "Public" or "Private" Function?}

Significant consequences follow from the answer to this question in a variety of legal contexts. ${ }^{e s}$ The question may appear simplistic insofar as unions perform both public and private functions. Nonetheless, the cases often require judges to focus on union activities that have both public and private dimensions and to determine which aspect is legally significant for a particular purpose. For example, bargaining over wages advances both the private economic interests of the members and, perhaps indirectly, the public interest in maintaining industrial peace and the uninterrupted flow of commerce. In the adjudication of some cases judges must be able to say which interest is legally significant-that, for example, wage-bargaining is a public function for purposes of the

64527 F. Supp. 1169 (E.D. Mich. 1981).

65 See id. 1174-75, 1178-79.

$60 \mathrm{Id} .1180$.

67 Id. 1178 (" $[t]$ he defendants are ordered and directed to conduct regular general membership meetings [pursuant to specified guidelines]. The meetings are to have set agendas, shall be attended and conducted by the elected local officers, be governed by Roberts Rules of Order where the Bylaws do not govern, and make reasonable allowance for free discussion of matters affecting union policy ... and other subjects normally a part of membership meetings of voluntary associations").

68 See infra note 74. 
matter at hand, even though everyone knows that it is both public and private in nature. There is, however, no principled or coherent method by which judges can choose the dominant aspect. Rather, selecting the characterization "public function" or "private function" is often a way of rationalizing a political choice in legal terms.

Cases involving the expenditure of compulsory union dues command attention because they may be explained comfortably in two different ways, each with precisely the opposite application of the public/private distinction. Pursuant to statute, which in the case of the Railway Labor Act preempts state law to the contrary, ${ }^{69}$ unions negotiate contracts with employers requiring union dues payments as a condition of employment ("union security agreements"). ${ }^{70}$ Yet such compelled dues payments impinge upon the first amendment rights of dissenting employees to be free from coerced financial support of organizations to which they might be deeply opposed on political or religious grounds. ${ }^{71}$

Under the prevailing approach to this problem, the courts' first step is to conclude that the public has a compelling interest in maintaining the system of private collective bargaining, so as to avoid industrial strife and insure free flow in the arteries of commerce. It is then concluded that because unions perform a public function in this scheme, they are entitled to "tax" all those who benefit from the fruits of collective bargaining. ${ }^{22}$ Justice Black once wrote, quite seriously, that Congress could have appointed the Secretary of Labor to bargain on behalf of workers, and assessed them a fee for the Secretary's services, but that instead Congress selected unions for this purpose. ${ }^{73}$ In sum, the warrant for author-

${ }^{69}$ Railway Labor Act, $\$ 2$, Eleventh, 45 U.S.C. $\$ 152$, Eleventh (1976). The corresponding provision of the NLRA is $\$ 8(a)(3), 29$ U.S.C. $\$ 158(a)(3)$ (1976), but under $\$ 14$ (b), 29 U.S.C. $\$ 164(\mathrm{~b})(1976)$, state union security law takes precedence over federal law.

${ }^{70}$ See generally NLRB v. General Motors Corp., 373 U.S. 734 (1963).

${ }^{71}$ See Abood v. Detroit Bd. of Educ., 431 U.S. 209, 222 (1977) ("To compel employees financially to support their collective bargaining representative has an impact upon their First Amendment interests."); see also International Ass'n of Machinists v. Street, 367 U.S. 740 (196I) (to avoid constitutional questions, Court construes Railway Labor Act to allow compulsory dues collection in private sector, but not unconsented expenditure of compulsory dues on political causes).

72 Abood, 431 U.S. at 222 ("such interference [with dissenters' first amendment rights as is created by union security agreements] is constitutionally justified by the legislative assessment of the important contribution of the union shop to the system of labor relations established by Congress"). Abood involved a public sector union, but the same rule applies in the private sector. See Railway Employees Dep't v. Hanson, 351 U.S. 225, 238 (1956) ("the requirement for financial support of the collective-bargaining agency by all who receive the benefits of its work is within the power of Congress under the Commerce Clause and does not violate either the First or the Fifth Amendments").

73 Street, 367 U.S. at 787 (Black, J., dissenting). 
izing unions to encroach on the first amendment rights of dissenting workers is that unions perform a vitally important public function. ${ }^{74}$

This public function analysis is also marshalled to explain why unions may not spend their compulsory dues money on political candidates or ideological causes to which the dissenters object. ${ }^{75}$ This prohibition on unconsented political expenditures even extends to political issues directly related to labor's interests. That is, the proscription covers precisely those types of political issues (among others) that are permissible subjects of union leafletting on the private property of the employer. ${ }^{76}$ The public interest in worker education sanctions the trespass, but apparently not the union's purchase of the leaflet with compelled dues. Lobbying,

74 The "public function" analysis is also used to explain why unions are entitled to deploy certain coercive disciplinary sanctions against strikebreaking members, even though the right to refrain from striking is protected against union coercion by NLRA $\S 8(\mathrm{~b})(1)(\mathrm{A}), 29$ U.S.C. $\$ 158(\mathrm{~b})(\mathrm{I})(\mathrm{A})$ (1976). See NLRB v. Allis-Chalmers Mfg. Co., 388 U.S. 175, 181-84 (1967).

Allis-Chalmers and its progeny, the so-called "fines cases," in turn raise yet another series of interesting public/private problems regarding the status and function of unions. See supra text accompanying notes 49-67. Allis-Chalmers suggests that unions are quasi-public agencies of federal labor policy, and for that reason entitled to wield certain disciplinary weapons at the expense of the statutory rights of dissenting employees. 388 U.S. at 181-84. At first glance one would think this quasi-public-status analysis would commend itself to Justice Douglas, ever anxious to apply constitutional standards to labor union conduct. See supra note 62; see also Street, 367 U.S. at 775-79 (Douglas, J., concurring) (union members should take constitutional rights with them into the group). However, the underlying moral claim for Justice Douglas is really that of individualism. In order to undercut the disciplinary powers accorded to unions in Allis-Chalmers, therefore, he adopts the posture that a union is merely a private, voluntary association, and therefore a member may avoid its discipline simply by resigning. See NLRB v. Granite State Joint Bd., 409 U.S. 213, 215-19 (1972).

The public function analysis also shows up in another unexpected place. The appeal of the concept is shown by the fact that Professor Feller, an ardent proponent of union autonomy, proposes that the proper standard for judicial review of union behavior toward individual employees in the grievance process should be borrowed from the standard for judicial review of agency action. See Feller, A General Theory of the Collective Bargaining Agreement, 61 CAIIF. L. REv. 663, 811-12 (1973) (proposing as the standard of fair representation in the grievance process conduct that is not "arbitrary, capricious [or] an abuse of discretion"; these words derive from the Administrative Procedure Act $\$ 10(\mathrm{e})(2)$ (A), 5 U.S.C. $\$ 706(2)(A)$ (1976)). The existing fair representation standard bars conduct that is "arbitrary, discriminatory, or in bad faith," Vaca v. Sipes, 386 U.S. 171, 190 (1967). Professor Feller grounds his proposal on the fact that in the grievance process a union "perform[s] a discretionary administrative function," that is, it takes on the mantle of a semipublic agency.

75 See Abood, 431 U.S. at 232-37. The same rule applies in the private sector. See Street, 367 U.S. at 750-70 (applying Railway Labor Act). The same principles, allowing compulsory dues collections but not unconsented political expenditures, have been applied to the NLRA. See, e.g., Kolinski v. Lubbers, 530 F. Supp. 728 (D.D.C. 1982); Havas v. Communications Workers, 468 F. Supp. 144 (N.D.N.Y. 1981); Beck v. Communications Workers, 468 F. Supp. 87 (D. Md. 1979).

70 See supra text accompanying notes $35-39$. 
supporting candidates, and propagandizing are deemed private, partisan activities, "unrelated" to the public function that justifies coerced collection of the dues money in the first place. The courts therefore hold that unions cannot, consistently with the first amendment, spend compelled dues for political purposes over dissenters' objections.

The standard analysis of the dues cases assumes what is plainly false-that the "political" and "economic" functions of unions can be meaningfully and precisely distinguished. ${ }^{77}$ Moreover, the effort to specify "public" and "private" roles for unions generates a complex set of legal problems for unions and courts. ${ }^{78}$ The prevailing rules invite mischievous judicial inquiry into the "lines between collective-bargaining activities, for which contributions may be compelled, and ideological activities unrelated to collective bargaining, for which such compulsion is prohibited." 79 In this instance the public/private distinction not only fails to resolve legal questions, it creates them.

In addition to these difficulties, however, there is an entirely different type of problem with the public function analysis, one more immediately relevant to this discussion. In the case of private sector collective bargaining there is an equally plausible explanation of the dues cases, one that is supported by existing labor law doctrine, but one that reverses the public/private analysis just described. It might well be argued that the reason the first amendment is not offended by dues expenditures on collective bargaining

77 Cf. Street, 367 U.S. at 800 (Frankfurter, I., dissenting) (the "political activity of American trade unions . . . [is] indissolubly relat[ed] to the immediate economic and social concerns that are the raison d'être of unions"); id. 814 ("[t]he notion that economic and political concerns are separable is pre-Victorian").

This analysis of the dues cases also assumes that corporations may have political privileges denied to unions. Business corporations are permitted to spend money on political advocacy over the objections of dissenting shareholders. First Nat'l Bank of Boston v. Bellotti, 435 U.S. 765 (1978) (striking down on first amendment grounds state statute prohibiting corporate expenditures on state referenda campaigns). Likewise, public utilities may take public positions on controversial political issues and force ratepayers to subsidize such advocacy. Consolidated Edison Co. v. Public Serv. Comm'n, 447 U.S. 530 (1980). The Consolidated Edison Court denied that its holding contemplates forced subsidization, 447 U.S. at 543 n.13. But Justice Blackmun's dissent persuasively demonstrates that the Court's decision is not susceptible to narrowing on this point, id. 551-55.

$78 \mathrm{Cf}$. Jacksonville Bulk Terminals, Inc. v. International Longshoremen's Ass'n, 102 S. Ct. 2675 (1982) (holding that politically motivated strikes are labor disputes for Norris-LaGuardia Act purposes); International Longshoremen's Ass'n v. Allied Int'l, Inc., 102 S. Ct. 1656, I664 (1982) ("[t]he distinction between labor and political objectives [is] difficult to draw in many cases").

79 Abood, 431 U.S. at 236. See, e.g., Ellis v. Brotherhood of Ry. Clerks, 91 L.R.R.M. (BNA) 2339 (S.D. Cal. I976) (union recreational and social activities held to be outside the sphere of collective bargaining activity). 
activities is that such activity is a private function naturally occurring in the private market without substantial governmental oversight. $^{80}$ Because public law merely tolerates union security agreements in the private sector but does not command them, under this view union security agreements do not trigger the full range of constitutional constraints. ${ }^{81}$ From this vantage, private séctor collective bargaining resembles the provision of electricity for a fee by a public utility, the sort of activity the Supreme Court now deems a private function. ${ }^{32}$ By contrast, this alternative approach to the dues cases would view lobbying, electoral activity, and propagandizing as by definition public activities because they impinge on the world of politics. Accordingly, governmental responsibility for compulsory dues payments is higher in this context, and constitutional norms govern. ${ }^{83}$

80 See, e.g., H.K. Porter Co. v. NLRB, 397 U.S. 99, 108 (1970) (the NLRA is fundamentally premised on a system of "private bargaining under governmental supervision of the procedure alone, without any official compulsion over the actual terms of the contract"). See generally Klare, supra note 3, at 458-68.

81 This perspective informs the concurring opinion of Justice Powell in Abood, 431 U.S. at 250-54. Powell's social vision is grounded upon a distinction between governmentally "authorized" conduct, like contracting, which does not ordinarily answer to the full range of constitutional constraints, and governmentally "compelled" conduct, which does. This "Reaganite" version of the public/private distinction corresponds roughly to the premodern division between the world of business, where the rule of law structures behavior "permissively," and the world of politics, where law operates "mandatorily." This perspective is central to the anomaly in Justice Rehnquist's thinking highlighted by Professor Brest, see Breśt, State Action and Liberal Theory: A Casenote on Flagg Brothers v. Brooks, 130 U. PA. L. Rev. 1296 (1982), namely, that Rehnquist is capable of believing that "state action" is absent when a warehouseman forecloses on a statutory lien. See Flagg Bros. v. Brooks, 436 U.S. 149 (1978). To the modern legal mind this notion is absurd, but perhaps sense can be made of it by seeing it as a reflection of a dichotomy between "business" (what warehousemen do) and "politics" (what state officers do).

82 See Jackson v. Metropolitan Edison Co., 419 U.S. 345 (1974).

$83 \mathrm{~A}$ parallel rationale was used to justify the sudden reversal by the National Labor Relations Board on the highly significant question whether governmental action is involved when the NLRB grants exclusive representative certification to a union guilty of race or sex discrimination. Leaving aside the very real danger that anti-union employers might use bogus precertification charges of discrimination simply to delay collective bargaining, presumably all would agree that Board certification constitutes a public act and therefore must conform to the requirements of the equal protection component of the fifth amendment's due process clause. The NLRB so ruled in Bekins Moving \& Storage Co., 211 N.L.R.B. 138 (1974). Shortly thereafter Bekins was overruled in Handy Andy, Inc., 228 N.L.R.B. 447 (1977). Needless to say, NLRB certification procedures did not undergo a "privatizing transformation" in the intervening years. The Handy Andy opinion, however, was strongly influenced by the Burger Court's notion that routine regulatory action that structures business conduct does not constitute "governmental action." See 228 N.L.R.B. at 449-52; see also Jackson v. Metropolitan Edison, 419 U.S. 345 ( 1974); Moose Lodge No. 107 v. Irvis, 407 U.S. 163 (I972). Powell's opinion in the Abood dues case, Rehnquist's opinions in Flagg Bros., Jackson, and Moose Lodge, and the NLRB's decision in Handy Andy, consistently advance the view that action by government is not "governmental action" for constitutional 
In sum, accepting the dubious proposition that the dues cases make sense, they can be explained in either of two ways: on the grounds that collective bargaining is a public function, whereas political advocacy is a private matter; or, at least with respect to private sector collective bargaining, on the grounds that collective bargaining is a private function, whereas compelled financial support of political advocacy involves a coerced ideological association in the public domain, repugnant to constitutional norms.

\section{F. Are Employment Rights "Public" or "Private" Rights?}

Significant consequences can flow from the determination that a particular workplace right is a "public" or "private" right. The chief implication of the public/private distinction in this context is that employees (and other "private" litigants) lose a significant measure of control over the enforcement of rights if "their" rights are denominated public rather than private. This loss of litigation control may result in a serious dilution of the underlying substantive rights.

Rights under the NLRA have traditionally been considered "public rights." 84 For example, according to this view, the NLRA's prohibition of retaliatory discharges ${ }^{85}$ protects a right of the public to industrial peace and free-flowing commerce and not a right of the worker to keep his or her job. Just semantics? Not quite. Because rights under the NLRA are public rights, a charging party has no guarantee that the NLRB's General Counsel will proceed on his or her charge and ordinarily no possibility of judicial review should the General Counsel decline to proceed. ${ }^{86}$ The General

law purposes if the government's action consists "merely" in structuring the environment for business behavior or performing routine tasks that underwrite private ordering in the business (i.e., "private") world. For a discussion of Justice Stewart's contribution to the "Reaganite" theory of "state action," see infra note 166.

84 See Amalgamated Utility Workers v. Consolidated Edison Co., 309 U.S. 261 (1940). The doctrine appeared recently in General Am. Transp. Corp., 228 N.L.R.B. 808 (1977) (Chairman Murphy, concurring). The origins of the "public right" doctrine are traced in Klare, Judicial Deradicalization of the Wagner Act and the Origins of Modern Legal Consciousness, 1937-1941, 62 Mins. L. Rev. 265, 310-18 (1978).

8529 U.S.C. $\$ 158(\mathrm{a})(3)(1976)$.

8629 U.S.C. $\$ 153$ (d) (1976). See Logan v. Zimmerman Brush Co., 102 S. Ct. 1148, 1155 n.6 (1982) (unfair labor practice enforcement "is controlled by the NLRB's General Counsel, and the Counsel's refusal to issue a complaint is generally not reviewable either by the Board or by the courts"); NLRB v. Sears, Roebuck \& Co., 421 U.S. 132, 138-39 (1975) ("Congress has delegated to the Office of General Counsel 'on behalf of the Board' the unreviewable authority to determine whether a complaint [of an unfair labor practice] shall be filed. The practical effect of this administrative scheme is that a party believing himself the victim of an unfair labor practice can obtain neither adjudication nor remedy under 
Counsel can settle an unfair labor practice case without the charging party's consent, ${ }^{87}$ and a successful charging party lacks standing to enforce Board remedies through the ordinary contempt procedures of the court of appeals. ${ }^{88}$ Parties aggrieved by NLRB representation proceedings are ordinarily barred from seeking direct judicial review of Board decisions. ${ }^{80}$ A parallel to the courts' "public right" doctrine regarding Board law is the prevailing "administrative vision" with respect to the enforcement of the union election provisions of title IV of the LMRDA.90 This approach, derived from Supreme Court and other case law, requires the Secretary of Labor in administering title IV to represent the "public interest," which includes but does not necessarily coincide with the complaining union member's interest. ${ }^{91}$

Some employment rights are deemed private rights. An important example is the right to equal employment opportunity under title VII,92 said to be securely vested in the individual. ${ }^{93}$ The Court has indicated that title VII rights are private by ruling, for example, that such rights cannot be waived in the collective bargaining process.94 Another example is provided by the em-

the labor statute without first persuading the Office of General Counsel that his claim is sufficiently meritorious to warrant Board consideration." (citation omitted)).

87 Although the General Counsel's power of unilateral settlement (settlement against the wishes of the charging party) has been upheld, it may not be unlimited. See generally authorities cited in The Developing Labor Law 834 (C. Morris ed. 1971) and The Developing Labor Law: Cumulattve Supplement 1971-75 448 (Bioff, Cohen \& Hanslowe eds. 1976).

88 Amalgamated Utility Workers, 309 U.S. at 265-66.

89 See American Fed'n of Labor v. NLRB, 308. U.S. 401 (1940).

9029 U.S.C. $\$ \$ 41-483$ (1976). See James, supra note 63 , at $299-300$ ("In the prevailing administrative vision, the Secretary [of Labor]'s role is to balance all the potentially competing interests in LMRDA enforcement. The Secretary is supposed to represent the 'public interest,' of which the complainant's interest is but a component. The public interest includes not only the specific aim of promoting union democracy by enforcing the principles of title $I V$, but also the interest in the union's freedom to run its affairs without interference, as well as a multiplicity of societal interests, such as economic stability, labor peace, industrial democracy, avoiding corruption in unions, and so on" (footnote omitted)). James credits" the "administrative vision" or "public right" perspective with a significant role in impeding title IV enforcement and thereby weakening the forces of union democracy. Id. 293-313.

91 James, supra note 63, at 300. See also Wirtz v. Bottle Blowers Ass'n, 389 U.S. 463, 475 (1968) ("Congress emphatically asserted a vital public interest in assuring free and democratic union elections that transcends the narrow interest of the complaining union member.").

9242 U.S.C. $\$ \$ 2000$ e to $2000 \mathrm{e}-17$ (1976 \& Supp. IV 1980).

.93 See Alexander v. Gardner-Denver Co., 415 U.S. 36, 51 (1974) ("Title VII . . . stands on plainly different ground [than collective bargaining rights]; it concerns not majoritarian processes, but an individual's right to equal employment opportunities.").

94 Id. 52. 
ployee's right to fair representation. ${ }^{95}$ While a union's breach of the duty of fair representation is considered an unfair labor practice, ${ }^{96}$ the Supreme Court has held that the exclusive primary jurisdiction of the NLRB does not preempt federal or state courts from hearing an individual's private cause of action for breach of the duty of fair representation. ${ }^{9 \tau}$ This important decision is grounded in part upon the fact that under the public right doctrine the NLRB might decline to proceed in some fair representation cases. ${ }^{98}$ The Court deemed this result unacceptable: "The existence of even a small-group of cases in which the Board would be unwilling or unable to remedy a union's breach of duty would frustrate the basic purposes underlying the duty of fair representation doctrine." 99

The problem with this argument is that it proves too much. The Court could plainly say the same about the Board's failure to remedy any class of cases. To put it another way, the purpose of the public right doctrine is to inhibit the enforcement of statutory guarantees, or at least to inhibit their enforcement through partyinitiated litigation. Whatever is lost thereby is thought to be outweighed by the advantages (some would say the intended disadvantages) of a centralized enforcement system based on prosecutorial discretion. The real issue is what sort of enforcement mechanism is desirable regarding a particular set of rights. Labelling rights either "public" or "individual-private" adds little to analysis of that problem.

Moreover, it is not at all clear why or even whether some workplace rights are public or private. Legislative history is typically useless on the subject. For example, notwithstanding an elaborate Supreme Court discussion to the contrary, ${ }^{100}$ Congress probably did not intend or expect unions to assume any duty of fair representation to minority or female employees at all. ${ }^{101}$

95 See supra note 60.

96 See Local Union No. 12, United Rubber Workers, I50 N.L.R.B. 312 (1964), enforced, 368 F.2d 12 (5th Cir. 1966), cert. denied, 389 U.S. 837 (1967). But see Miranda Fuel Co., 140 N.L.R.B. 181 (1962), enforcement denied, 326 F.2d 172 (2d Cir. 1963). The prohibition of unfair labor practices protects public rights, see supra note 84 , yet this particular unfair labor practice infringes a private right, see infra text accompanying notes 97-99.

97 See Vaca v. Sipes, 386 U.S. 171, 176-88 (1967).

98 Id. 182-83.

99 Id.; cf. id. 182 n.8 ("[t]he public interest in effectuating the policies of the federal labor laws, not the wrong done the individual employee, is always the Board's principal concern in fashioning unfair labor practice remedies").

100 Steele v. Louisville \& N.R.R., 323 U.S. 192, 199-204 (1944) (duty of fair representation implied from Railway Labor Act on basis of analysis of congressional intent).

101 H. HILL, BLack Labor and the AMerican Legal System 93-106 (I977) (Congress rejected efforts to proscribe union race discrimination in Wagner Act). 


\section{Clayton $v$. United Auto Workers}

Determining the status of a particular right raises complications, as illustrated by Clayton $v$. United Auto Workers. ${ }^{102}$ An employee brought suit against his employer for allegedly discharging him without just cause in violation of the collective bargaining agreement, and against his union for alleged unfair representation in deciding not to process his grievance over the discharge to binding arbitration. This type of suit is known as a "301-DFR action," although it is frequently and inaccurately described as a "301 action." 103 Both defendants argued that the employee's failure to appeal the union's decision through available internal union appeals procedures barred subsequent action against them. The Supreme Court ruled that "where an internal union appeals procedure cannot result in reactivation of the employee's grievance or an award of the complete relief sought in his $\$ 301$ suit, exhaustion will not be required with respect to either the suit against the employer or the suit against the union." 104

Clayton contains at least two formulations of the public/private distinction: first, whether the employee's hybrid claim against the union and the employer touches matters in the public domain or questions solely of internal union affairs; and second, whether the preferred remedies in such cases are "judicial" or "private."

\section{a. Whether the Dispute is "Public" or "Private"}

The first question arises in Clayton because the two defendants invoked the federal labor policy of "forestalling judicial interference with internal union affairs." 105 "The Court ruled that this policy does not extend to issues "in the public domain and beyond the internal affairs of the union." 106 The Court distinguished between "internal" union matters "such as those involving the interpretation and application of a union constitution," 107 and matters in the "public" domain, such as disputes involving unfair labor practice charges by a member against his or her union. ${ }^{108}$ Because

102451 U.S. 679 (1981).

103 The numerical reference derives from the source of law governing suits on the collective bargaining contract, $\S 301(a)$ of the Labor Management Relations Act (LMRA), 29 U.S.C. $\$ 185(a)$ (1976).

104 Clayton, 451 U.S. at 685.

105 Id. 687.

106 Id. 688 (citation omitted) (quoting NLRB v. Marine Workers, 391 U.S. 418,426 n.8 (1968)).

$107 \mathrm{Id}$.

108 Id. 688 \& n. 14. 
Clayton involved an alleged breach of the statutory duty of fair representation, the Court determined that it raised issues of public policy "extending far beyond internal union interests." 109

This version of the public/private distinction may be reformulated as a distinction between disputes involving public policy and rights and private disputes. Such a distinction is untenable, not because some disputes are on the "borderline," but because all intraunion and interunion disputes are in both domains. The very fact that a case is in court subject to federal law, thereby giving rise to a legal question whether the court should defer or withhold its process, means that a wrong offensive to the concerns of public policy has been alleged. The Supreme Court has specifically held that a suit by a local union against a parent international union alleging a violation of the international's constitution may be maintained in federal court. ${ }^{110}$ The Court found that such cases suffciently implicate the national policy of labor stability as to warrant the extension of federal jurisdiction over them. ${ }^{111}$

True, there may be some disputes that turn entirely on questions of "private law"-for example, a suit between local labor unions over leased premises or over the purchase and sale of office equipment. The Court left open whether such suits may be maintained in federal court.112 But to claim that these are "purely private" disputes simply amounts to a conclusion of public policy, namely that the federal interest in labor stability does not require public regulation or federal judicial oversight of this particular class of cases. That the courts are open at all for resolution of such disputes indicates at least a minimal level of public concern..$^{113}$ In any event, almost all litigation between members and unions and most litigation between unions touches substantial public interests

109 Id. 688.

110 See United Ass'n of Journeymen \& Apprentices of the Plumbing \& Pipefitting Indus. v. Local 334, 452 U.S. 615 (1981) (treating disputes over union constitutions as disputes over "contracts between labor organizations" within the meaning of $\$ 301$ (a) of the LMRA).

111 Id. 624 ("Surely Congress could conclude that the enforcement of the terms of union constitutions... would contribute to the achievement of labor stability."). 112 Id. 627.

113 See generally Cohen, The Basis of Contract, 46 HARv. L. REv. 553 (1933). A contract. . . cannot be said to be generally devoid of all public interest. If it be of no interest, why enforce it? For note that in enforcing contracts, the government does not merely allow two individuals to do what they have found pleasant in their eyes. Enforcement, in fact, puts the machinery of the law in the service of one party against the other. When that is worthwhile and how that should be done are important questions Id. 562 . of public policy. 
in union democracy and responsible union behavior. The very existence of internal union appeals procedures reflects, if it does not always derive from, the public interest in preventing autocracy and promoting autonomy and democracy within unions.

\section{b. Whether the Remedy Should Be "Public" or "Private"}

The second public/private issue arises in Clayton because of the well-established aspect of "national labor policy that encourages private rather than judicial resolution of disputes arising over collective-bargaining agreements." 114 The Court noted that this policy might be relevant to Clayton insofar as a rule requiring aggrieved employees to exhaust internal union remedies in 301: DFR actions might promote nonjudicial, private resolution of such disputes. ${ }^{115}$ The Court, however, declined to impose a universal exhaustion requirement. It reconciled its holding against the requirement with its continuing preference' for private remedies by distinguishing the Clayton facts from cases in which, among other criteria, the internal union appeals procedures could result in reactivation of the employee's grievance or an award of the full relief sought in the 301-DFR action. ${ }^{116}$. The underlying claim in Clayton was for breach of the collective bargaining contract, raising precisely the type of issue most clearly appropriate for nonjudicial resolution. Ironically, the employee succeeded in getting his day in court because the private dispute-resolution system involved was not structured so as to guarantee him a private resolution of his grievance.

The Court's contrast between judicial and private resolution of disputes arising out of collective bargaining agreements may be reformulated as a distinction between judicial and arbitral processes, it being assumed that the arbitral process is "private." Classifying arbitration as a "private" system, however, is problematical to say the least. ${ }^{117}$ Some argue that insofar as support for arbitration is so important a component of national labor policy, it is plausible to view arbitration as a public governance system for the workplace. Accordingly, the argument goes, the difference between the courts and arbitration is not so much a public/private distinction as one between agencies of public power: There are, of course, counterarguments of great practical and theoretical significance to this view of arbitration. ${ }^{118}$ The point here is only that the Court's simple

114 Clayton, 451 U.S. at 689.

$115 \mathrm{Id}$.

116 Id.

117 See supra text accompanying notes 23-30.

118 See Klare, supra note 3, at 458-68. 
equation of the court/arbitration -and public/private distinctions obscures rather than illuminates important issues demanding more probing analysis.

\section{2. benShalom v. Secretary of the Army}

A final example of the contrast between public and private rights is benShalom $v$. Secretary of the Army, ${ }^{119}$ a landmark case recognizing a right to sexual preference in public sector employment. This example is related to but also somewhat different from the previous ones. First, the term "private right" here connotes not only that the holder of the right is a private individual but also that the right owes its existence to a concept of protecting "privacy" from public intrusion. The "opposite" of such a rightfor example, a right of the public to a sexually pluralist environment-is difficult to articulate and has few if any analogues in our legal discourse..$^{200}$ Nevertheless, the point of the example is that the characterization of the right to sexual preference as a "privacy right" has significant, narrowing consequences for its substantive definition. Second, because. labor law already treats the previous examples. in terms of an explicit public/private contrast, the focus of discussion there was on contradictions and incoherence in prevailing doctrine. Here the analysis explores the substantive consequences of basing the right to sexual preference solely on the notion of "privacy." The purpose of the discussion here is to contrast prevailing law with an alternative conception of how rights to sexual identity and expression might be protected.

benShalom holds unlawful the discharge of a soldier from the United States Army Reserve on grounds of homosexuality. The district court determined that the regulation under which the Army processed benShalom's discharge violates the first amendment rights of free expression and association. ${ }^{121}$ Perhaps more significantly, the court also found that the first, fourth, fifth and ninth amendments embody a "personal privacy right" that, if it "means anything... . safely encompass[es] an individual's right to be free from unwarranted governmental intrusion into matters so fundamentally. affecting a person as one's personality, self-image, and indeed, one's very identity." 122 .

119489 F. Supp. 964 (E.D. Wis. 1980).

120 One example might be provided by the common interpretation under which the first amendment protects not only dissenting speech by individuals but also a general interest in having a kind of society that encourages the free, pluralistic exchange of ideas.

121489 F. Supp. at 974.

122 Id. 975. 
This is a visionary holding, an historic step forward in protecting the civil rights of gay people. It ought to be law in every jurisdiction. Nonetheless, the decision to protect freedom in matters of sexual preference under the rubric of a personal right to privacy has problematical consequences. For one thing, by resting on a traditional John Stuart Mill-conception of the public/private distinction, ${ }^{123}$ the court suggests that disciplinary considerations might justify the Army and possibly other public employers. in regulating the sexual conduct, as opposed to the identity, of their employees. ${ }^{124}$ How can this distinction between identity and conduct be tenable? "Self-hood" and "personality" by definition have expressional, communicative, and associational dimensions, as the court's first amendment reasoning acknowledges. ${ }^{125}$ Collective identity nurtures personal identity; the self without others does not exist. ${ }^{126}$ Moreover, the court's formulation has a stigmatizing effect, most notably in its blame-the-victim suggestion that benShalom holds her constitutional rights on the condition of sexual abstinence. ${ }^{127}$

Ideally, the law should not only create zones of privacy and protect victimized employees, but it should also recognize a public right of employees to work in a sexually pluralistic environment. In this view, the workplace is one of people's most important learning environments. This approach would therefore require employers to undertake a public responsibility to facilitate sexual awareness and choice by combatting sexual prejudice and coercion and by establishing a workplace atmosphere that allows all people to explore and express their sexual identities. Employers would be required not only to take affirmative action to hire gay men and women, but to provide a work setting conducive to gay pride. While benShalom enlarges human freedom in important aspects of employment, the case stops short of full protection of sexual preference because it rests on a sharp demarcation between public and private dimensions of working life. At the same time, benShalom contains the insight that personal identity has an interactive and communicative component. The emancipatory potential of the case can only be fully

123 J. Mirl, ON Liberty ch. 1 (A. Castell ed. 1947).

124 benShalom, 489 F. Supp. at 976.

125 Id. 974.

126 See generally G. Hegel, The Phenomenology of Mind (J. Baille trans. 2d ed. 1967); K. MARx, Economic and Philosophical Manuscripts, in EARLX WRTTINGs, supra note 35, at 279; J. SARTRE, BEING AND Nothungness (H. Bames trans. 1956).

127 benShalom, 489 F. Supp. at 975 (error of the Army's position is that it assumes homosexual employee will engage in homosexual activity, whereas she might forego sexual activity). 
realized when its logic is extended to the communal aspects of working life.

\section{The Shifting Contours of Public/Private Imagery in the Collective Bargaining Context}

Few categories are as central to the organization of collective bargaining theory as the public/private distinction. The cases are replete with ringing affirmations of the centrality of the public/ private distinction as a basic principle of analysis. One of the most salient of such reminders is Justice Black's opinion for the Court in H.K. Porter Co. $v$. NLRB: 128

One of [the] fundamental policies [of the NLRA] is freedom of contract. While the parties' freedom . . . is not absolute under the Act, allowing the Board to compel agreement when the parties themselves are unable to agree would violate the fundamental premise on which the Act is based-private bargaining under governmental supervision of the procedure alone, without any official compulsion over the actual terms of the contract. ${ }^{129}$

Scholars and commentators are similarly at pains to recite the importance of the public/private distinction. A leading text confidently intones: "The basic theory of the [NLRA] in its original form, as today, was that the arrangement of substantive terms and conditions of employment was a private responsibility from which the government should stand apart." 130

Despite all this, it is apparent from the evolution of collective bargaining law that the public/private distinction has no general

128397 U.S. 99 (19.70) (NLRB may not order employer to accede to a particular contract clause as remedy for egregious refusal to bargain in good faith).

${ }^{129}$ Id. 108 (footnotes omitted); cf. NLRB v. American Nat'l Ins. Co., 343 U.S. 395, 402 n.26 (1952) (citing Terminal R.R. Ass'n v. Trainmen, 318 U.S. 1, 6 (1943)):

The Railway Labor Act, like the National Labor Relations Act, does not undertake governmental regulation of wages, hours, or working conditions. Instead it seeks to provide a means by which agreement may be reached with respect to them. The national interest expressed by those Acts is not primarily in the working conditions as such. So far as the Act itself is concerned these conditions may be as bad as the employees will tolerate or be made as good as they can bargain for.

130 A. Cox, D. Bok \& R. Gorman, Cases and Materuals on Labor Law 84 (8th ed. 1977); cf. id. 93 ("the Taft-Hartley [amendments of 1947] abandoned the notion that law has no role to play in the handling of labor disputes .... Nevertheless, the points at which the Taft-Hartley Act revives legal intervention into everyday disputes are trivial in comparison to those it leaves untouched"); id. 766 ("national labor policy [relies] primarily on private adjustments of conflicting interests ... instead of on determination by law"). 
significance; it takes on meaning only in a particular historical and political context.

The modern history of the labor injunction provides a preeminent example of this point. During the $1930 \mathrm{~s}$ public/private imagery was deployed to justify judicial withdrawal from the labor relations field, ${ }^{131}$ as seen most notably in the 1932 Norris-LaGuardia anti-injunction act. ${ }^{132}$ By the 1970s, however, public/private rhetoric in labor relations law was recast so as to justify judicial intervention. A significant instance is the doctrine of Boys Markets v. Retail Clerks Union Local 770,133 which allows courts to grant injunctive relief against strikes over arbitrable grievances, notwithstanding Norris-LaGuardia. The contemporary view is that there is a significant public interest in avoiding midcontract work-stoppages over employee grievances. In the words of the Boys Markets Court: "congressional emphasis [has] shifted from protection of the nascent labor movement to the encouragement of collective bargaining and to administrative techniques [principally grievance and arbitration procedures] for the peaceful resolution of industrial disputes." ${ }^{134}$ By the time of Boys Markets, judicially enforced adherence to grievance-arbitration agreements had become a "dominant motif" and a "kingpin of federal labor policy." ${ }^{135}$

It might appear that during both the 1930s and the 1970s a consensus existed on the need for demarcation between public and private, and that nothing had changed but the categorization of certain subjects. In this view, all that occurred in the case of grievance strikes was a gradual reconsideration of the particular issue, leading to a conclusion that on balance it should be transferred from the domain of private ordering to the realm of public responsibility. In fact, a great deal more was involved. The very idea of "private enterprise" had to be transformed so as to make it comfortable to believe what earlier was almost inconceivable: that private enterprise and managerial prerogative are consistent with a legal regime that makes employer responses to employee grievances a matter of public policy.

131 See infra text accompanying notes 137-53.

13229 U.S.C. $\$ \$ 101-115$ (1976); see id. $\$ 101$ ("[n]o court of the United States ... shall have jurisdiction to issue any restraining order or temporary or permanent injunction in a case involving or growing out of a labor dispute, except in a strict conformity with the provisions of this chapter").

133398 U.S. 235 (1970). See generally infra notes 238-43 and accompanying text.

134 Boys Mkts., 398 U.S. at 251.

135 Sinclair Ref. Co. v. Atkinson, 370 U.S. 195, 225-26 (1962) (Brennan, J., dissenting). In Boys Markets the Court, per Justice Brennan, overruled Sinclair and explicitly adopted the position of the Sinclair dissent. 
Part II will describe the gradual redefinition between 1935 and 1970 of the boundaries between the public and private spheres, as seen from the vantage of the theory of private sector collective bargaining law. The premise of the exercise is that we will better appreciate the ideological messages encoded in the legal rules if we trace the chameleon-like alterations in public/private imagery rather than treating the public/private distinction as in itself conceptually meaningful.

\section{A. Prewar Public/Private Imagery}

It is remarkable that at a time when the viability of the public/ private distinction was under attack in most political and legal contexts, the philosophy of labor law reform embodied such resolute faith in the distinction. A central theme of the politics of the 1930s was the challenge to the supposed independence of business and politics. Similarly, one of the most important developments in legal thought was the Legal Realists' criticisms of the traditional conception of "private ordering." The gist of these criticisms was. that so-called private ordering in fact amounts to a system of social control implicating issues of public policy. ${ }^{136}$ The movement to enact the NLRA was informed by these political and intellectual currents.

Nonetheless, the NLRA was grounded upon and justified by reference to a rudimentary version of public/private rhetoric. The basic philosophy of the Wagner Act was that labor problems would be resolved by a private process of negotiation and contracting, backed up by the threat or use of self-help measures to secure bargaining advantage. ${ }^{137}$ The specifics of the statutory scheme were fashioned in keeping with this vision.

True enough, the law contains some provisions of an interventionist mold, provisions that curtail private managerial prerogative. Notable examples are the employer's obligations to re-

136 See supra note 113. See generally Fuller \& Perdue, The Reliance Interest in Contract Damages (pts. 1-2), 46 YALE L.J. 52, 373 (1936-37); Hale, Bargaining, Duress, and Economic Liberty, 43 Colum. L. Rev. 603 (1943); Hale, Force and the State: A Comparison of "Political" and "Economic" Compulsion, 35 Colum. L. Rev. 149 (1935); Jaffe, Law Making by Private Groups, 51 Hanv. L. Rev. 201 (1937); Kessler, Contracts of Adhesion-Some Thoughts About Freedom of Contract, 43 Colum. L. Rev. 629 (1943); Nerken, A New Deal for the Protection of Fourteenth Amendment Rights: Challenging the Doctrinal Bases of the Civil Rights Cases and State Action Theory, 12 Harv. C.R.-C.L. L. REv. 297, 339-60 (1977).

137 See Cox, supra note 16, at 322 ("[t]he Wagner Act became law on the floodtide of the belief that the conflicting interests of management and worker can be adjusted only by private negotiation, backed, if necessary, by economic weapons, without the intervention of law"). 
frain from interference with employee self-organization and to recognize and bargain with majority unions. ${ }^{138}$ The need for these interventionist provisions stemmed from a corollary of the Act's basic philosophy, namely the premise that there is a public interest in promoting unionization as a form of private power. It was believed that for the private ordering system to function effectively and thereby to foster industrial peace, there had to be some "clout" on the employees' side. This was to be achieved by allowing and encouraging workers to pool their bargaining power. ${ }^{139}$ Clearly, though, the mission of public law was narrowly limited to the task of establishing and maintaining an effective private bargaining system.

The two foremost symbols of the private bargaining orientation-the plan to keep the law "out" of labor-management relations -were first, the narrow scope of the employer's duty to bargain collectively favored by many proponents of the Act; and-second, the withdrawal of federal equity jurisdiction regarding labor disputes. ${ }^{140}$ The duty to bargain was one of the provisions of the Act most bitterly opposed by employers, who saw in it a mortal threat to their sovereignty in the workplace. ${ }^{141}$ To sell the Act politically, to defend it against constitutional attack, and to reassure employers and nudge them toward reconciliation with collective bargaining, prominent proponents of the statutory scheme were at some pains to insist that it did not contemplate government supervision of the substantive terms and conditions of employment.

138 These obligations were imposed by the Wagner Act, the original version of the NLRA, $\$ 8(1),(2),(3),(5), 49$ Stat. 449 (1935), (codified as amended at 29 U.S.C. $\$ 158$ (a) (1), (2), (3) (proscription of employer interference), (5) (duty to bargain) (1976)).

139 See NLRB v. Insurance Agents' Int'l Union, 361 U.S. 477, 506-07 (1960) (separate opinion of Justice Frankfurter) (citation omitted):

The main purpose of the Wagner Act was to put the force of law behind the promotion of unionism as the legitimate and necessary instrument "to give laborers opportunity to deal on equality with their employer" . . . Equality of bargaining power between capital and labor ... was the aim of this legislation.

140 Norris-LaGuardia Act, 29 U.S.C. $\$ \$ 101-115$ (1976). See suprd note 132.

$141 \mathrm{I}$ have argued elsewhere at some length that these fears were plausible. Klare, supra note 84, at 281-93. My views on this point are criticized in Comment, The Rad:cal Potential of the Wagner Act: The Duty to Bargain Collectively, 129 U. PA. L. REv. 1392 (1981). The comment misunderstands my point. I did not claim that Congress "intended" a radical interpretation of the Act. My point was that it was and is impossible to determine precisely what Congress did intend, that at the time the Act was passed it was susceptible to a radical interpretation, and that therefore employers plausibly feared that such an interpretation would evolve. Accordingly, the evidence adduced in the comment simply does not rebut mý claims. Indeed, the only relevance of such evidence is that much of it tends to prove my point that congressional intent was unclear. 
Thus, perhaps the most important instance in American history of public regulation of the workplace was contemporaneously defended and justified on the ground that it would not interfere with private determination of working conditions. Friends of collective bargaining anxious to promote employer reconciliation encouraged a narrow interpretation of the duty to bargain, one that eschews governmental supervision of the content and as much as possible of the conduct of the employer's bargaining posture. ${ }^{142}$ The battle cry for such advocates was a renowned and oft-quoted passage from the legislative history. This passage neatly captures the mid-1930s view of the public/private distinction in its metaphor of a doorway, a precise demarcation between the public and private realms:

When the employees have chosen their organization, when they have selected their representatives, all the bill proposes to do is to escort them to the door of their employer and say, "Here they are, the legal representatives of your employees." What happens behind those doors is not inquired into, and the bill does not seek to inquire into it. ${ }^{143}$

Also symbolic of the "privatization" of the new federal labor policy was the Norris-LaGuardia Act of 1932,144 the primary purpose of which was to bar the federal courts from issuing injunctions in cases arising out of labor disputes save in the most exceptional circumstances. ${ }^{145}$ Although neutral in theory, courts of equity, particularly federal courts, had systematically intervened in labor disputes on the employers' side, aggressively so since the late nineteenth century. ${ }^{146}$ Before Norris-LaGuardia the labor injunction had been a primary legal weapon in employers' efforts to forestall the progress of organized labor. Congress's 1932 command that the federal courts henceforth refrain from wielding that weapon represented a dramatic shift of public policy toward "deregulation" of labor conflict. Today one commonly thinks of deregulation as a pro-business strategy, but, at least in this instance, the intent was pro-labor. In light of the history of judicial bias in favor of man-

142 See Klare, supra note 84 , at 293-310. 158.

14379 CoNG. REc. 7660 (1935) (statement of Senator Walsh). See infra note

14429 U.S.C. $\$ \$ 101-115$ (1976).

145 See id. $\$ 104$ (specific acts, such as peaceful picketing, not enjoinable in cases involving or growing out of labor disputes); id. $\$ 107$ (stringent procedural and substantive barriers to issuance of any injunction in labor dispute cases). (1930).

146 See genetally F. Frankfurter \& N. Greene, The Labor Injunction 
agement, the idea behind Norris-LaGuardia was that labor's strength and organization would grow and unions would best be enabled to produce results for employees under a regime of judicial abstention.

To provide philosophical underpinnings for such abstention, proponents of Norris-LaGuardia fastened on public/private rhetoric. The Act was widely justified by virtue of its connection to a larger vision, the view that industrial problems are best left to the private conflict and accommodation of economic forces: ${ }^{147}$

The Norris-LaGuardia [Act] marks the high water mark of the philosophy that law had no useful role to play in labor relations. Its thesis was that so long as unions and employers refrain from fraud, violence and intimidation, their pursuit of self-interest is to be left to the competitive struggle with the outcome ultimately depending upon economic power. ${ }^{148}$

Indeed, the principle of remitting industrial disputes to the private sphere was a crucial selling point of New Deal labor law reform to organized labor as well as to employers. Labor was suspicious of the federal government because of the unhappy experience of over half a century of government-sponsored strikebreaking, not only through the labor injunction but also through repressive legislation such as the antitrust laws, military intervention, federal court nullification of progressive reforms, and so on. ${ }^{149}$ In this respect labor's need for reassurances against undue governmental involvement in the collective bargaining process closely paralleled management's fears. Liberal proponents of collective bargaining therefore sought to allay the qualms of both groups by insisting

147 One should note, however, that in at least one significant respect the NorrisLaGuardia Act narrowed rather than enlarged the scope of private ordering. Section 3, 29 U.S.C. $\$ 103$ (1976), declared void as against public policy the so-called "yellow dog" contract, in which an employee promises not to join a labor union. The "illegality" or "voidness as against public policy" doctrine is a classic instance of social control of the private contracting system.

148 Cox, Current Problems in the Law of Grievance Arbitration, 30 Rockr MTN. L. REv. 247, 253-54 (1958).

149 The philosophy behind the labor legislation of the nineteen thirties was deeply rooted in the disappointing experience of half a century of legal intervention into industrial conflicts. ... Congress turned [to] the policy of relying for the adjustment of industrial conflicts upon negotiation between employers and labor organizations strong enough to bargain effectively on behalf of employees. Judicial intervention into strikes, boycotts or picketing was prohibited partly because it did nothing to resolve the underlying problems and partly because the injunction was traditionally a weapon for weakening employee organization.

Cox, supra note 16 , at 323 . 
that publicly sponsored collective bargaining would for the most part be a private system of industrial conflict resolution.

To the contemporary eye, most notably absent from the model of collective bargaining promoted by 1930's labor law reform is any suggestion that management responses to day-to-day worker grievances ought to be deemed a concern of public policy, let alone a "dominant motif" of federal labor policy as it is today. 150 Employers feared that NLRB enforcement of the duty to bargain might lead to public supervision of contract terms, ${ }^{151}$ and additional attention to public control of midcontract labor problems would only have exacerbated their concerns. To be sure, the notion of collective bargaining as a continuous rulemaking process was available in the most advanced labor relations thinking and literature. However, it does not seem to have influenced deeply the actual design of and early decisions under the Wagner Act. ${ }^{152}$ The 1935 statutory scheme provided no governmental machinery for the airing and adjustment of midcontract grievances. For a variety of reasons, this problem was to become a focal point in the development of labor law over the next thirty-five years. ${ }^{153}$

\section{B. The Postwar Transformation (I): Expansion of the Public Role}

The most salient characteristic of postwar collective bargaining law is the redefinition of the role of public intervention in the collective bargaining process, a change often capsulized in the notion that the "public sphere" expanded at the expense of the "private sphere." As will be seen, this summary characterization correctly highlights the dominant trend of public expansionism. It is misleading, however, unless qualified by the observation that the real and symbolic significance of private autonomy in the collective bargaining process, particularly for employers, has also undergone a theoretical and doctrinal revival in the postwar years. ${ }^{154}$ Rather than viewing the period as one of uniform, glacier-like governmental encroachment on the private sphere, it is perhaps

150 See supra note 135 and accompanying text.

151 See Klare, supra note 84 , at 287-88.

152 See generally Stone, supra note 3, at 1514-22 (early expressions of governmental theory of collective bargaining; absence of contract enforcement machinery under Wagner Act).

153 See infra notes $207-43$ and accompanying text. See generally Klare, supra note 3; Stone, supra note 3.

154 See infra notes 180-201 and accompanying text. 
more helpful to focus on the simultaneous and mutually reinforcing metamorphoses of both the public and private spheres in labor law.

The private sphere has maintained an unyielding integrity of its own, and, hence, some equilibrium in the public/private contraposition. Still, it is ultimately true that the postwar period witnessed a pronounced drift toward public expansionism. In terms of Senator Walsh's famous metaphor, ${ }^{155}$ the law has not only crossed the threshold and passed through the doorway, but it permeates the atmosphere of the employer's office. ${ }^{158}$ Three major components of this trend are the increased legal regulation of collective bargaining negotiations, the expanded judicial role in administering the collective bargaining contract, and increased statutory regulation of the employment relationship.

\section{Legal Intervention in the Bargaining Relationship}

Justice Black's dictum notwithstanding, ${ }^{157}$ the law today profoundly influences the procedure, subject matter, and even the substance of collective bargaining. The law dictates, where it is obeyed, the topics about which management and labor may or must bargain. ${ }^{158}$ It sets limits on when the use of economic weapons is permissible. ${ }^{159}$ It establishes certain rules of bargaining conduct that the parties must observe in their own behavior ${ }^{100}$ or tolerate in that of their adversary. ${ }^{161}$

155 See supra text accompanying note 143.

156 Cf. Cox, The Duty to Bargain in Good Faith, 71 Harv. L. Rev. 1401, 1403 (1958) ("[T] he law has crossed the threshold into the conference room and now looks over the negotiator's shoulder. Is the next step to take a seat at the bargaining table?").

157 See supra text accompanying note 129.

158 See, e.g., NLRB v. Wooster Div. of Borg-Warner Corp., 356 U.S. 342 (1958) (employer or union may insist on negotiations over "mandatory" subjects of bargaining); cf. Fibreboard Paper Prods. Corp. v. NLRB, 379 U.S. 203, 219 n.2 (1964) (Stewart, J., concurring) ("There was a time when one might have taken the view that the National Labor Relations Act gave the Board and the courts no power to determine the subjects about which the parties must bargain - a view expressed by Senator Walsh when he said that public concern ends at the bargaining room door. . . . But too much law has been built upon a contrary assumption for this view any longer to prevail ....") (citations omitted).

150 Thus, for example, an implication of Borg-Warner and its progeny is that unions may not strike to enforce their will with respect to so-called "permissive" subjects of collective bargaining.

100 See, e.g., NLRB v. Katz, 369 U.S. 736 (1962) (prohibition of unilateral changes); NLRB v. Truitt Mfg. Co., 351 U.S. 149 (1956) (obligation to provide information).

101 See, e.g., NLRB v. Insurance Agents' Int'I Union, 361 U.S. 477 (1960) (although not protected, concerted on-the-job activities designed to pressure employer during negotiations are not proscribed by the duty to bargain in good faith). 
Moreover, decisions under the NLRA and other statutes can influence or determine the content of collective bargaining contracts, either by designating certain categories of agreement as impermissible ${ }^{162}$ or by altering the underlying, precontractual allocation of workplace rights and responsibilities.

Two recent cases illustrate the latter point. In $N L R B v$. J. Weingarten, Inc., ${ }^{163}$ the Supreme Court enlarged the interpretation of the "rights of employees" guaranteed by section 7 of the NLRA ${ }^{164}$ to include an employee's right to union representation at investigatory interviews that the employee reasonably believes may result in disciplinary action. In $N L R B \quad v$. Magnavox Co., ${ }^{165}$ the Court held that employee leafletting rights derived from section 7 cannot be waived by a collective bargaining contract. Decisions of this kind alter the distribution of rights and powers with which bargaining commences and therefore alter the substantive outcomes of bargaining. In each case dissenters urged that the Court had engineered an improper statutory incursion into the area of workplace law that should properly be left to private ordering. ${ }^{166}$ Of

162 See, e.g., Pacific Maritime Ass'n v. Federal Maritime Comm'n, 435 U.S. 40 (1978) (upholding Federal Maritime Commission scrutiny of collective bargaining agreements under Shipping Act for anticompetitive restraints); Connell Constr. Co. v. Plumbers \& Steamfitters Local 100, 421 U.S. 616 (1975) (judicial scrutiny of collective bargaining activities for antitrust violations); Local 189, Amalgamated Meat Cutters v. Jewel Tea Co., 381 U.S. 676 (1965) (same); United Mine Workers v. Pennington, 381 U.S. 657 (1965) (same).

163420 U.S. 251 ( 1975 ).

16429 U.S.C. $\$ 157$ (1976).

165415 U.S. 322 (1974).

166 See Weingarten, 420 U.S. at 270 (Powell, J., joined by Stewart, J., dissenting) ("An employee's right to have a union representative ... at an investigative interview is a matter that Congress left to the free and flexible exchange of the bargaining process."); Magnavox, 415 U.S. at 330 (Stewart, J., joined by Powell and Rehnquist, JJ., concurring in part and dissenting in part) ("in nullifying the union's promise to waive the literature-distribution rights of its own supporters, the Board and today the Court are upsetting the delicate balance acheved in the give and take of negotiations and presenting the union with an undeserved windfall.").

As these cases indicate, the theme of governmental regulation versus private ordering is a hallmark of Justice Stewart's labor law opinions. Perhaps the contractualist influence on his thinking induced his defection from the anti-affirmative action alliance in Regents of the Univ. of Cal. v. Bakke, 438 U.S. 265 (1978) (recognizing constitutional restrictions on state-mandated affrmative action plans), to the pro-affirmative action majority in United Steelworkers v. Weber, 443 U.S. 193 (1979) (upholding collectively bargained affirmative action plan). Justice Stewart cast an important swing-vote in Weber.

Stewart's unique perspective on the public/private distinction raises serious questions germane to this symposium. In a remarkable opinion issued just prior to his resignation from the Court he wrote that "[s]o far as the Constitution goes, a private person may engage in any racial discrimination he wants, cf. Steelworkers v. Weber, ... but under the Equal Protection Clause of the Fourteenth Amendment a sovereign state may never do so." Minnick v. California Dep't of Corrections, 452 U.S. 105, 128 (1981) (Stewart, J., dissenting) (citation omitted). 
course the dissenters overlook the obvious point that a decision not to expand the scope of section 7 rights also implicates public law in the initial assumptions and, hence, in the substantive outcomes of collective bargaining.

\section{The Enlarged Judicial Role In Contract Administration}

Another aspect of governmental intrusion into the hitherto private sphere of labor-management relations involves the proliferation of federal common law of the collective contract. ${ }^{167}$ While

This sentence is astounding for several reasons, even leaving aside the gratuitous characterization of the affirmative action program in the Weber case as a form of race discrimination. It is not entirely clear that the Constitution permits private persons to engage in any species of race discrimination. The thirteenth amendment may directly forbid forms of race discrimination constituting "badges and incidents of slavery." See City of Memphis v. Greene, 451 U.S. 100, 124-25 (1981) (leaving question open and asserting that exercise of congressional power under the thirteenth amendment is not inconsistent with the view that the amendment has self-executing force): In any event, the thirteenth amendment authorizes Congress to forbid certain forms of race discrimination by private individuals. See Runyon v. McCrary, 427 U.S. 160 (1976) (Stewart, J.) (thirteenth amendment allows Congress to condemn private acts of race discrimination); Jones v. Alfred H. Mayer Co., 392 U.S. 409 (1968) (Stewart, J.) (same). Moreover, it is late in the day to view a complex collective bargaining agreement such as was involved in Weber as the act of a "private person." Cf. Steele v. Louisville \& N.R.R., 323 U.S. 192, 202 (1944) (Railway Labor Act imposes upon union in the collective bargaining process "at least as exacting a duty to protect equally the interests of the members of the craft as the Constitution imposes upon a legislature to give equal protection to the interests of those for whom it legislates").

For purposes of this discussion Justice Stewart's Minnick opinion is most interesting because it aligns him with what I have called the "Reaganite" version of the public/private distinction. See supra notes 81 \& 83 (Justices Powell and Rehnquist). By this I mean a view of the world in which there is a sharp division between the realm of government ("public") and the realm of business ("private"). Thus, just as the warehouseman's foreclosure on a statutory lien is "private" for Justice Rehnquist because it is ordinary business behavior, see Flagg Bros. v. Brooks, 436 U.S. 149 (1978), the negotiation of a major collective bargaining agreement of national significance is "private" for Justice Stewart because it is routine conduct in the business world. A great irony of Minnick is that it places Justice Stewart's thinking on private sector collective bargaining-i.e., his notion that government permits but does not compel the parties to structure their agreement in any particular way-in precise alignment with Justice Powell's pointed criticisms of Justice Stewart's opinion for the Court in Abood v. Detroit Bd. of Educ., 431 U.S. 209, 245-50 (1977) (Powell, J., concurring in the judgment). See supra notes $80-83$ and accompanying text.

Justice Stewart has made other contributions to the Reaganite public/private theory. One of the most important and grotesque is Stewart's recent defense of the view that government bears no responsibility for the unequal social distribution of income. See Harris v. McRae, 448 U.S. 297, 316-17 (1980) (upholding constitutionality of denial of Medicaid funding for therapeutic abortions, in part on the ground that government's decision to deny funding does not constitute a governmentally created obstacle to poor woman's exercise of freedom of choice).

107 See Cox, supra note 148, at 254 ("Since [1947] it has been clear that law and judicial sanctions are a vital part of the national labor policy not only in the organizational phase of labor relations but also in the negotiation and administration of collective agreements."). 
vast areas of the law of the shop remain under the control of the parties, the postwar period saw a pronounced propensity of courts to override party-intent in the administration of collective bargaining agreements. ${ }^{168}$ Of course, by itself judicial intervention of this kind is not news. What is unusual about the courts' postwar role, especially in light of the then still recent experience of the labor injunction, is the relatively systematic and sophisticated way the courts used their contract enforcement powers to play a role in making overall policy regarding the nation's labor relations. This is seen most notably in the emergence of the federal labor policy favoring enforced adherence to collectively bargained arbitration procedures.

In service of this goal, the courts have preferred interpretations of collective contracts favorable to binding arbitration. Some such interpretations are plausible and, in any event, relatively easy for the parties to avoid by renegotiation if they are unintended. ${ }^{169}$ More recent instances have involved strained and improbable constructions, some flying in the face of the clearest evidence of the parties' intent. A striking example is the Court's literally incredible interpretation of the National Bituminous Coal Wage Agreement in Gateway Coal Co. v. United Mine Workers. ${ }^{170}$ Gateway Coal announces that in order for employees to reserve the statutory right to strike under a contract containing a broad arbitration clause, the contract must explicitly negate the implied nostrike obligation raised by the employer's promise to arbitrate disputes. $^{171}$ This rule of construction has been applied elsewhere, with devastating effect upon workers' statutory rights and with at best dubious fidelity to contractual intent. ${ }^{172}$ It is difficult in light

${ }^{168}$ A dramatic example is the Court's questionable interpretation of the contract in Local 174, Teamsters v. Lucas Flour Co., 369 U.S. 95 (1962) (implied promise not to strike). Justice Black's scathing dissent lays bare the Court's cavalier treatment of party-intent. Id. 108 ("I had supposed .. . though evidently the Court thinks otherwise-that the job of courts enforcing contracts was to give legal effect to what the contracting parties actually agree to do, not to what courts think they ought to do.").

169 See, e.g., United Steelworkers v. Warrior \& Gulf Navigation Co., 363 U.S. 574 (1960) (strong presumption in favor of arbitrability of grievances).

170414 U.S. 368 (1974) (injunction against mine safety strike). The implausibility of the Court's construction is painstakingly demonstrated in Atleson, Threats to Health and Safety: Employee Self-Help Under the NLRA, 59 MrN. L. Rev. 647, 664-86 (1975).

171 Gateway Coal, 414 U.S. at 382.

172 See, e.g., Goya Foods, Inc., 238 N.L.R.B. 1465 (1978) (extension of nostrike obligation beyond the term of contract). 
of such cases to maintain the fiction that the collective contract is simply an expression of the will of private parties. ${ }^{173}$

\section{Direct Statutory Regulation of the Employment Relationship ${ }^{174}$..}

The dramatic expansion of federal and state statutory. programs regulating the employment relationship is perhaps the most important category of postwar public law "incursions" into labormanagement affairs. Some of these statutory developments reflect a political consensus that collective bargaining has not and perhaps cannot by itself resolve certain basic social problems of the workplace: race, sex, and other forms of invidious discrimination in employment, ${ }^{175}$ the dangers of occupational injury and disease, ${ }^{176}$ and problems of retirement income security. ${ }^{177}$ Others reflect a political consensus that public scrutiny of internal union decisionmaking, finances, and other practices is necessary, ${ }^{178}$ that is, that public power should be deployed to curb perceived abuses of private group power. ${ }^{179}$

\section{The Postwar Transformation (II): The Resurgence of Privatism}

During the same period that witnessed the waves of public expansionism in collective bargaining law just discussed, the ideal of

${ }^{173}$ Cf. Lynd, Investment Decisions and the Quid Pro Quo Myth, 29 CASE W. Res. L. Rev. 396, 411-13 (1979) (discussing Textile Workers Union v. Lincoln Mills, 353 U.S. 448 (1957)). Lynd makes the point that in interpreting the arbitration and no-strike provisions of the contract at bar in Lincoln Mills, the Court focused entirely on the intent of Congress in enacting section 301 of the Labor Management Relations Act (LMRA), 29 U.S.C. \$185 (1976), not the intent of the parties to that contract

174 On the themes of this paragraph, see generally Hyde, Beyond Collective Bargaining: The Politicization of Labor Relations Under Government Contract, 1982 WIs. L. REv. 1, 38-40 (1982) (growth of federal statutory restrictions on the terms and conditions of employment); Feller, supra note 25, at 123-25 (changing status of the autonomous system of collective bargaining centered on arbitration traced in part to increased statutory regulation of employment relationship).

175 See, e.g., Equal Pay Act of 1963, 29 U.S.C. $\$ 206(d)$ (1976); title VII of the Civil Rights Act of 1964, 42 U.S.C. $\$ \$ 2000 \mathrm{e}$ to $2000 \mathrm{e}-17$ (1976 \& Supp. IV 1980); Age Discrimination in Employment Act of 1967, 29 U.S.C. $\$ \$ 621-634$ (1976 \& Supp. IV 1980); Rehabilitation Act of 1973, 29 U.S.C. \$\$701-796i (1976 \& Supp. IV 1980).

176 See Occupational Safety and Health Act of 1970, 29 U.S.C. $\$ \$ 651-678$ (1976 \& Supp. IV 1980).

177 See Employee Retirement Income Security Act of 1974, 29 U.S.C. $\$ \$ 1001$ 1381 (1976 \& Supp. IV 1980).

178 See supra note 60.

170 Cf. supra text accompanying note 139. 
private autonomy was refurbished and reinvigorated in profoundly important ways. The explanation for this conjugate development lies in the ideological functions of the public/private distinction. It is impossible for contemporary legal discourse to jettison public/ private imagery by overly favoring the public side. The ideal of private ordering possesses enormously potent ideological valences in our political culture, both as a source of institutional values and as a symbolism. It is therefore carefully cultivated even as public regulation expands.

Four major aspects of the resurgence of privatism in contemporary collective bargaining law are the waiver principle, deference to arbitration, the management prerogatives doctrine, and the narrowing of employee self-help rights.

\section{The Waiver Principle}

The "waiver principle" is used here to denote the preeminence in modern labor-management relations of the contract as a legal device and collective bargaining as a political process designed to induce employees to surrender, for a price, their statutory rights to concerted activity and coparticipation in enterprise governance. ${ }^{180}$ The no-strike clause, express or implied, is the mechanism by which unions trade employees' right to strike during the contract term. ${ }^{181}$ The management-rights clause is the device by which employees alienate their statutory right to participate through collective bargaining in determining the terms and conditions of employment. ${ }^{182}$

The emphasis labor law places upon the collective contract tends to legitimate it as the preeminent source of law in the organized workplace ${ }^{183}$ and as the ultimate goal of the employees' unionization struggle. The law tends to diminish the value of other forms of concerted activity and to proscribe some that do not fit the contractualist mold, such as wildcat strikes. ${ }^{184}$ The overall

180 This point is developed in Klare, Labor Law and the Liberal Political Imagination, Soctalist Rev., Mar.-Apr. 1982, at 45, 51-53, 57-61.

181 See generally Local 174, Teamsters v. Lucas Flour Co., 369 U.S. 95 (1962) (implied no-strike obligation); Senate Comm. ON Labor and Public Welfare, Enforcement of Contract Responsibilities, S. Rep. No. 105, 80th Cong., Ist Sess. 15-18 (legislative history of LMRA \$301 emphasizes importance of enforcement of contractual no-strike promises).

182 See NLRB v. American Nat'l Ins. Co., 343 U.S. 395 (1952) (management-rights clause providing for exclusive managerial control of mandatory subjects of collective bargaining during the term of the contract is itself a mandatory subject as to which management may bargain to impasse). 174.

${ }^{183}$ But see supra text accompanying notes $174-79$ and sources cited in note 184 See infro notes $195-97$ and accompanying text. 
thrust is to channel employee aspirations into conventional economic demands. ${ }^{185}$ Yet focusing on the contract as the primary repository of employee rights deflects scrutiny from the terms of the waivers involved. It suggests instead that the reality or appearance of due process in the bargaining stage endows negotiated working conditions with the imprimatur of justice, no matter how onerous or inequitable they may be.

\section{Deference to Arbitration}

The policy of judicial ${ }^{186}$ and administrative ${ }^{187}$ deference to grievance arbitration is a second "privatizing" theme in modern collective bargaining law. We have already noted that whether the arbitral forum is itself "private" is a question not entirely free from complexity. ${ }^{188}$ Nonetheless, labor law decisionmaking has been deeply informed by the theory that grievance arbitration is an autonomous, private dispute-resolution system that serves the cause of industrial peace precisely because it is so responsive to the needs and concerns of the parties. ${ }^{189}$ Whether or not this is an accurate and useful view of grievance arbitration, there can be no doubt that the deference slogan has vested the private institutional parties to collective bargaining, the employer and the union, with enormous power and latitude in fashioning industrial common law. ${ }^{190}$

\section{Management Prerogatives}

A third way in which private power, in this case the employer's power, maintains control over the collective bargaining process is through the principle of management prerogative, particularly as manifested in the "subjects of bargaining" doctrine. We have previously focused on this area as a prime instance of governmental

185 See infra notes 191-92 and accompanying text.

180 See United Steelworkers v. Enterprise Wheel \& Car Corp., 363 U.S. 593 (1960) (judicial deference to arbitration); United Steelworkers v. Warrior \& Gulf Navigation Co., 363 U.S. 574 (1960) (same); United Steelworkers v. American Mfg. Co., 363 U.S. 564 (1960) (same).

187 See Carey v. Westinghouse Elec. Corp., 375 U.S. 261 (1964) (NLRB deference to arbitration); Collyer Insulated Wire, 192 N.L.R.B. 837 (1971) (same); Speilberg Mfg. Co., 112 N.L.R.B. 1080 (1955) (same).

188 See supra notes 23-30 \& 117-18 and accompanying text.

189 See Warrior \& Gulf Navigation Co., 363 U.S. at 578-81; cf. Shulman, Reason, Contract, and Law in Labor Relations, 68 HARv. L. Rev. 999 (1955) (emphasis in discussing collective bargaining on autonomy of the parties' private system of industrial self-government).

$100 \mathrm{Klare}$, supra note 3 , at 458-68, develops the ideological significance of the point that the basic "charter" or "statute" of the industrial rule of law, the collective bargaining agreement, represents the expression of the will of private parties. 
power over the substance of collective bargaining. ${ }^{191}$ It is equally important to emphasize the aspect of the "subjects" doctrine that safeguards the exercise of private power. The purpose and effect of denominating some subjects "nonbargainable" is to permit private power to supersede public law norms and conceptions of industrial democracy with respect to such issues. The effort to shelter capital investment decisions, particularly regarding plant relocation and closure, from employee participation has manifested a cancerous growth in American labor law in recent times. This development has been facilitated by ringing Supreme Court pronouncements that

[the duty to bargain does not extend to] managerial decisions, which lie at the core of entrepreneurial control. Decisions concerning the commitment of investment capital and the basic scope of the enterprise are not in themselves primarily about conditions of employment, though the effect of the decision may be necessarily to terminate employment ... [ [T]hose management decisions which are fundamental to the basic direction of a corporate enterprise ... should be excluded from [the] area [subject to the duty of collective bargaining]. ${ }^{192}$

So important is the "core of entrepreneurial control" doctrine that it has totally perverted the interpretation of the National Labor Relations Act. Under the currently prevailing test for determining whether a particular type of managerial decision is subject to the duty to bargain, ${ }^{193}$ the advocates of mandatory bargaining over significant industrial decisions must demonstrate that the public interest in workplace democracy, as expressed through government-fostered collective bargaining, outweighs the inconvenience of collective bargaining to private power-holders. But Congress settled that issue in 1935, in general and largely unqualified terms. The very purpose of the NLRA is to "encumber" managerial decisionmaking with a collective bargaining process, precisely because the value of employee participation is deemed to outweigh the foreseeable inconvenience of collective bargaining to

191 See supra notes $158-59$ and accompanying text.

192 Fibreboard Paper Prods. Corp. v. NLRB, 379 U.S. 203, 223 (1964) (Stewart, J., concurring).

$193[\mathrm{I}] \mathrm{n}$ view of an employer's need for unencumbered decisionmaking, bargaining over management decisions that have a substantial impact on the continued availability of employment should be required only if the benefit, for labor-management relations and the collective bargaining process, outweighs the burden placed on the conduct of the business.

First Nat'l Maintenance Corp. v. NLRB, 452 U.S. 666, 679 (1981). 
the employer. The Court's new "standard for "interpreting" the NLRA therefore really amounts to a subversion of its most basic premises and serves only to ratify the existing hierarchy of power. ${ }^{194}$

\section{Loss of Section 7 Rights..}

A fourth aspect of the resurgence of privatism is a set of legal developments depriving employees of rights to self-organization and concerted activity. In form such developments represent public regulation of the collective bargaining arena. In substance they are definitions of or changes in the groundrules designed to bolster the primacy of the employer's economic power by penalizing certain types of employee activity designed to counteract it. The outstanding example is the Taft-Hartley statutory prohibition against secondary boycotts. ${ }^{195}$ Others are the proliferating doctrines designed to remove legal protection from certain kinds of employee concerted activity ${ }^{196}$ and those limiting the right to strike. ${ }^{197}$

194 For an exceptionally interesting discussion of the management prerogatives doctrine, see J. Atleson, Values \& Assumptions in AMErucan Labor Law 140212 (forthcoming, 1983) (manuscript copy on file with the University of Pennsylvania Law Review).

195 See NLRA $\$ 8(b)(4), 29$ U.S.C. $\$ 158(b)(4)$ (1976); LMRA §303, 29 U.S.C. $\$ 187$ (1976).

196 It is extraordinary how much of the law of NLRA $\$ 7,29$ U.S.C. $\$ 157$ (1976), pertains to ways in which employees may lose rather than gain $\$ 7$ rights. See, e.g., supra notes 16-22 and accompanying text. Section 7 rights can be lost in three main ways:

(a) by waiver: see NLRB v. J. Weingarten, Inc., 420 U.S. 25I, 257 (1975) (employee may waive right to be accompanied by union representative at investigatory interview); Local 174, Teamsters v. Lucas Flour Co., 369 U.S. 95 (1962) (waiver of right to strike by union); NLRB v. American Nat'l Ins. Co., 343 U.S. 395 (1952) (waiver by union of bargaining rights during contract term through "management functions" clause);

(b) by operation of law: see supra note 16 (disruption and indefensible disloyalty); Emporium Capwell Co. v. Western Addition Community Org., 420 U.S. 50 (1975) (loss of protection for concerted activity that undermines the "majority rule" principle of federal labor policy); NLRB v. Allis-Chalmers Mfg. Co., 388 U.S. 175 (1967) (to preserve united front unions may discipline strikebreakers despite statutory right of employees to refrain from concerted activity); NLRB v. Fansteel Metallurgical Corp., 306 U.S. 240 (1939) (concerted activity involving misconduct such as sit-down strike is unprotected); NLRB v. Mackay Radio \& Tel. Co., 304 U.S. 333 (1938) (business needs supersede $\$ 7$ rights, allowing permanent replacement of economic strikers); of. Leviton Mfg. Co. v. NLRB, 486 F.2d 686 (Ist Cir. 1973) (employment-related legal action filed in bad faith not protected by $\$ 7$ ). Note also that conduct constituting an unfair labor practice is unprotected, see R. GorMan, supra note 37, at 303-05;

(c) by inadequate enforcement: see, e.g., Kowal, The Shocking State of the Board's Section 8(a)(3) Decisions, 4 InDus. REx. L.J. 308 (1981) (weaknesses in NLRB approach to discrimination cases result in significant dilution of employee rights under NLRA).

197 See, e.g., International Longshoremen's Ass'n v. Allied Int'l, Inc., 102 S. Ct. 1656 (1982) ("political" strikes prohibited as secondary boycott); Linden Lumber 
The examples of public intervention previously discussed, such as the judicial role in administering the collective bargaining contract, generally involve governmental regulation of both management and labor. Any claim that such developments favor one side or the other can only be proved by reference to some extra-legal or ideological factor. In the short-run, at least, these legal developments purport to impose equally on both sides. The category of public interventions now under discussion, however, acts directly against the interests of one of the parties-labor-for the purpose of depriving that side of weapons it previously employed in the free play of collective bargaining.

Direct public intervention against one party contravenes the overriding initial premise of collective bargaining theory that the public has no interest in any particular contract outcome, but only an interest in maintaining a sparsely regulated bargaining process. ${ }^{198}$ Such intervention, particularly by judges, should be doubly suspect to the liberal mind because it appears so uncomfortably similar to the ignominious pattern of suppressing unions through the labor injunction and antitrust adjudication. ${ }^{199}$ Because it is somewhat inconsistent with the overall ideology of labor law, such intervention requires special justification. The rhetoric has been exceedingly inflated. For present purposes the most interesting device is to appeal to the conscience of a fictional "public" or "community" in order to legitimate the public promotion of private, partisan interests.

A classic example is provided by Professor Cox's justification of the decisions removing section 7 protection from slow-downs, concerted refusals to work overtime, unannounced work-stoppages and other "disruptive" tactics. One could argue that concerted midcontract interruptions of the production process are contrary to the national interest, a point of view that invites debate. Instead Cox writes, without citation, that "[s]uch decisions reflect an ap-

Div. v. NLRB, 419 U.S. 30I, 306 (1974) (increased risks in recognitional strikes due to ruling that picket-line majority does not give rise to duty to bargain); Gateway Coal Co. v. United Mine Workers, 414 U.S. 368 (1974) (enjoinability of safety strikes); Boys Mkts., Inc. v. Retail Clerks Local 770, 398 U.S. 235 (1970) (revival of the labor injunction against grievance strikes).

198 See supra text accompanying notes 137-49.

199 Cf. Duplex Printing Press Co. v. Deering, 254 U.S. 443, 488 (1921) (Brandeis, J., dissenting):

The conditions developed in industry may be such that those engaged in it cannot continue their struggle without danger to the community. But it is not for judges to determine whether such conditions exist, nor is it their function to set the limits of permissible contest and to declare the duties which the new situation demands. 
parently deep-seated community sentiment ... . [T] here can be little doubt of the general public condemnation of occupying a job and taking pay while simultaneously refusing to perform the services required." 200

Similarly, in explaining the proscription of secondary boycotts a leading textbook on collective bargaining remarks that

the Taft-Hartley Act abandoned the notion that law has no role to play in the handling of labor disputes. ...

. . Nevertheless, the points at which the Taft-Hartley Act revives legal intervention into everyday disputes are trivial in comparison to those it leaves untouched. Also, the law intrudes only in areas where the overwhelming consensus of opinion condemns the unlawful conduct. ${ }^{201}$

Here again a decision to deprive a private participant in the "free" collective bargaining process of a crucial weapon is justified in the name of an illusory moral sentiment of an illusory community, rather than by more candidly acknowledging the obvious point that using public power to structure the private ordering process always has a differential impact on private needs and interests. It is particularly ironic that a diffuse notion of communal moral sentiment, rather than a more pointed reference to the antilabor policies of the Congress that enacted Taft-Hartley, is invoked to justify suppression of the secondary boycott. This is a tactic that in many situations can succeed only by an appeal to employees and/or consumers to put aside their immediate self-interest and convenience in the name of solidarity. That is, to an unusual degree the tactic requires an appeal to authentic communal bonds.

\section{The Logic of Postwar Public Expansionism}

This part concludes by examining the pressures within and around the collective bargaining system that produced an evolution from the private ordering orientation of the 1930s to today's more public interventionist model. In particular, the focus will be on explaining the dramatic alteration of the public/private boundary line with respect to employer responses to day-to-day grievances. The review that follows suggests a general tension within the

200 Cox, supra note 16, at 338 . Compare the rhetoric cited in the text with a more candid alternative explanation Cox provides for the slowdown decisions, namely that slowdowns and similar tactics are simply too effective to permit workers to have such weapons in their bargaining arsenal. Id. 338-39; see supra note 16 .

201 A. Cox, D. Box \& R. GonMan, supra note 130, at 93. 
public/private distinction that renders it inherently unstäble and therefore at all times prone to evolutionary transformation. On particular issues, private actors may perceive an ad hoc interest in appealing to public power so as to reinforce their position within the private sphere. Private actors are thus frequently torn between a desire generally to preserve the public/private separation, on the one hand, and recurring "short-run" reasons to disturb it, on the other. This tension combines with external social forces to generate a continuous evolutionary process in public/private discourse.

As discussed above, ${ }^{202}$ prewar collective bargaining theorists navigated carefully between the Scylla of public control of the employment relationship and the Charybdis of total "deregulation." The theoretical difficulty was to justify some measure of public regulation of the workplace while stopping well short of anything resembling administrative determination of working conditions. A solution to this difficulty was found in developing a modernized principle of contractualism as the foundation of workplace justice. ${ }^{203}$ The model of private contract was adhered to even during World War II, when pursuant to executive order ${ }^{204}$ and statute ${ }^{205}$ the federal government had extraordinary powers, including an effective power to make substantive decisions regarding terms and conditions of employment. Once collective bargaining became widespread and the contract became the central focus of collective bargaining, attention centered on the mechanisms of contract enforcement. Success in developing these mechanisms has made aspects of the collective bargaining contract quite attractive to management, accounting in part for the extent to which American employers have become reconciled to collective bargaining. ${ }^{206}$

Today the collective contract is primarily administered through arbitration, with an underlying regime of court enforcement for special situations. This was not true before World War II, when the arbitral system as we now know it did not exist. ${ }^{207}$ Nor were the courts the primary locus of prewar collective contract enforcement, although the collective contract was legally enforceable. Such

202 See supra text accompanying notes 137-53.

203 See supra text accompanying notes 180-82. See generally Klare, supra note 84 , at $293-336$.

204 Exec. Order No. 9017, 3 C.F.R. 1075 (1938-1943 compilation), reprinted in 9 L.R.R.M. (BNA) 945 (1943).

205 See, e.g., Economic Stabilization Act, ch. 578, 56 Stat. 765 (1942) (expired 1944); War Labor Disputes Act, ch. 144, 57 Stat. 163 (1943) (expired 1947).

206 See generally Feller, A General Theory of the Collective Bargaining Agreement, 61 CAXIF. L. REv. 663, 720-24, 760-71 (1973).

207 See id. 745-47. 
contracts were enforced primarily through self-help. ${ }^{208}$ The slowdown and strike were the union's tools, and discipline and the lockout were management's in a continuing process of contract administration through power-conflict.

During the war, the right to strike was legally curtailed, and in any event the labor movement had pledged not to strike. It was therefore politically desirable for the War Labor Board to provide an alternative to conflict-resolution through self-help. That alternative was binding arbitration, which became virtually mandatory under the encouragement and directives of the War Labor Board. ${ }^{209}$

An enormous strike wave erupted when the war ended, ${ }^{210}$ unleashing years of pent-up energy and anger at controlled wages and unresolved grievances, and shortly thereafter Taft-Hartley was enacted. Taft-Hartley reflected both a sharp rightward turn in the political climate and the triumph of a long-term effort by employers, delayed by the war, to reverse the processes set in motion by the Wagner Act and the rise of the CIO. It was clear, however, that the clock could not be set back before 1935. The political reality of the immediate postwar years was that the spread of unionization might be arrested and contained but that the major collective bargaining relationships were too firmly entrenched to be dislodged. Accordingly, attention was again focused on the means of administering the collective contract. In this context an extraordinarily gifted generation of liberal labor lawyers, judges, professional arbitrators, management theorists, and law teachers devoted their energies to developing a model of collective bargaining that could both commend itself to the labor movement and earn a measure of reconciliation from American employers. Naturally the grievance arbitration procedures that had impressed so many labor leaders and managers during the war were destined to be central to this model. ${ }^{211}$

In a nutshell, the leading postwar labor law issue became how to make contractualism work effectively. From the employers'

208 Id. 745.

209 Id. 746-47.

210 In fact, the war years themselves witnessed a staggering amount of strike activity, notwithstanding labor's no-strike pledge. See Green, Fighting on Two Fronts: Working Class Militancy in the 1940's, Radicar Axr., July-Aug. 1975, at 7, 7-21. See also Lynd, supra note 173 , at 415 \& n.106.

211 Although query ' whether employees were equally impressed. See supra note 210. Note that professional arbitrators, many of whom got their start as such under the aegis of the War Labor Board, also pushed for a collective bargaining model centered on arbitration. See generally Beeferman, Labor Arbitration in the Post-War Era: Concepts, Institution, and Consciousness 3-17 (June 1977) (unpublished manuscript on file with the University of Pennsylvania Law Review). 
standpoint the key problem was to achieve efficient and durable enforcement of the no-strike provisions of collective bargaining agreements ${ }^{212}$ and thereby to obtain uninterrupted production during the term of the contract. ${ }^{213}$ Management wanted to preserve the benefits it derived from private ordering-for example, minimal governmental scrutiny of working conditions and minimal compulsory bargaining with respect to managerial decisionmaking. At the same time management wanted greater public intervention so as to deny unions a crucial component of what they had gained from the privatized, "deregulated" 1930s labor-management process, namely the right and/or effective power to strike over midcontract grievances.

Leading commentators decried the notion of relying on the judiciary to enforce collective bargaining agreements. The most famous was the outstanding arbitrator and law teacher Harry Shulman, who pointedly suggested that the "law stay out . . ."214 It followed from his perspective that when the parties' autonomous rule of law and private negotiations failed to resolve disputes, resort had to be allowed, however reluctantly, to self-help: "When their autonomous system breaks down, might not the parties better be left to the usual methods for adjustment of labor disputes rather than to court actions on the contract or on the arbitration award?" 215

However, the pressure was overwhelming to take another road than Shulman's. A foremost priority of mainstream labor law in the postwar period became to enlist the law in the task of suppressing midcontract grievance strikes. Employers and liberal theorists embarked on the venture of mobilizing public power (notably that of the federal courts in section 301 cases) ${ }^{216}$ in order to protect

212 The primary purpose of LMRA $\$ 301$ (a), 29 U.S.C. $\$ 185$ (a) (1976), was to serve this goal. See Senate Comm. on Labor and Public Welfare, supra note 181, at 15-18 (legislative history of $\$ 301$ focuses on a variety of legal impediments to enforcement of collective contracts in the state courts).

213 See Senate Comm. on Labor and Public Welfare, supta note 181, at 16 (" $[t]$ he chief advantage which an employer can reasonably expect from a collective labor agreement is assurance of uninterrupted operation during the term of the agreement").

214 Shulman, supra note 189, at 1024. Shulman wrote:

When the [arbitration system] works fairly well, it does not need the sanction of the law of contracts or the law of arbitration. It is only when the system breaks down completely that the courts' aid in these respects is invoked. But the courts cannot, by occasional sporadic decision, restore the parties' continuing relationship; and their intervention in such Id. cases may seriously affect the going systems of self-government.

215 Id.

216 See supra note 212. Statutory change was also important. Section 8(d) of the NLRA, 29 U.S.C. $\$ 158$ (d) (1976), inserted by the Taft-Hartley amend- 
private rights (the benefit to employers of no-strike clauses) by elevating such private rights to a superior position over employees' public rights (notably the statutory right to concerted activity for mutual aid).

The other side of the coin is that labor too had something to gain, or so its leaders believed, from bringing the law "in" to the labor-management process. If for practical, legal, and/or political reasons self-help was no longer viable as the chief means of contract enforcement, then strengthening the alternative system of grievance arbitration was absolutely essential in order to provide workers a measure of industrial due process during the contract term. From labor's standpoint the arbitral system compared favorably to the judicial process. Arbitration was perceived as much more informal and accessible than the courts, and much more responsive to the values of industrial democracy and the special needs of industrial parties. Because its flexibility and responsiveness made it attractive to labor, those interested in labor-management reconciliation naturally underscored the autonomy of arbitration in constructing their ideal model of collective bargaining.

Curiously, some proponents of the arbitration system saw a need to bring law "in" precisely in order to save arbitration from the law. Conservative courts, which did not appreciate or approve the sometimes counterintuitive norms of arbitral law, threatened the autonomy and vitality of the system by excessive interference. ${ }^{217}$ It was thought that only a dramatic intervention emanating from a preeminent source of law could arrest the corrosive intrusion of the lower courts and thereby preserve the "autonomous" arbitration system. A second great priority of postwar labor law was, therefore, to find that source of law and to establish its hegemony. Labor union lawyers and liberal theorists embarked on the venture of mobilizing public power (notably that of the federal courts in section 301 cases) in order to protect private interests (an autonomous arbitration system based to a significant degree on industrial and party-controlled norms, rather than legalistic and externally

ments, makes it unlawful for a union to strike during the term of a collective bargaining contract when the objective is to "terminate or modify" the contract. However, the $\S 8$ (d) prohibition "does not apply when the union's strike protests employer action which the union in good faith and with colorable basis asserts is in violation of the contract." R. GorMAN, supra note 37, at 423 . That is, the no-strike provisions of $\$ 8(d)$ do not apply to grievance strikes. This is why the enforcement of contractual no-strike guarantees under $\$ 301$ became so important. 217 The leading case was International Ass'n of Machinists v. Cutler-Hammer, Inc., 271 A.D. 917, 67 N.Y.S.2d 317, affd, mem., 297 N.Y. 519, 74 N.E.2d 464 (1947) (court interprets collective contract in ruling on motion to compel arbitration). 
imposed norms) by elevating this private arbitration system to a central place in public policy. ${ }^{218}$

As can be seen, both employers and unions perceived convincing reasons to invoke public regulatory power to reinforce their interests, although not only management but labor as well remained wary of public intervention in the private arena of labor-management affairs. Sophisticated legal thinkers and advocates gradually worked out a "package" of legal reforms that appeared to advance some of the interests of both sides. ${ }^{219}$ As the elements of the package gradually unfolded, an integrated vision of the collective bargaining process emerged and was in large part adopted as law. The intellectual power of this synthesis and the convergence of partyinterest around an enhanced role for public law helped generate the pressures toward public expansionism so evident in postwar labor law.

The basic package ${ }^{220}$ involved a tradeoff: the employer agreed to submit midcontract disputes to binding arbitration, and the union committed itself to a legally enforceable no-strike obligation. ${ }^{221}$ The idea of promoting this tradeoff in order to suppress

218 See supra text accompanying notes 24-30; cf. supra text accompanying note 216.

219 It is not suggested that only labor was interested in the arbitration side of the no-strike/arbitration tradeoff. The most sophisticated management thinkers developed a theory in which the "web of rules" flowing from the continuous grievance arbitration process is treated as an essential component of management control in the workplace. This point is developed at some length in Klare, supra note 3, 459-65 (citing literature). However, the interests of individual, rank-and-file employees were not closely attended to in the development of this synthesis.

220 The compressed nature of this presentation regrettably suggests a conspiracy, or at any rate implies that the lawyers and academics who promoted the "package" possessed a high degree of self-consciousness and foresight about what they were doing. This overtone is not intended. On the contrary, the ideas comprising the package were developed slowly and erratically, in fits and starts. A few of those involved may have understood and subscribed to all the major tenets of the tradeoff. Perhaps the best example is Justice Douglas. But many or even most participants in the legal developments described here did not support the entire package nor did they necessarily perceive all of its implications. For an interesting and detailed discussion of the intellectual history of the period, see generally Beeferman, supra note 211. Accordingly, references to the "package" or to an integrated vision of the collective bargaining process point not to an explicit program of an identifiable faction but to the unfolding logic and overall structure of legal thought about collective bargaining problems during this time.

221 This arrangement is often called a "quid pro quo." See, e.g., Buffalo Forge Co. v. United Steelworkers, 428 U.S. 397, 407 (1976); Boys Mkts., Inc. v. Retail Clerks Local 770, 398 U.S. 235, 248 (1970); Textile Workers Union v. Lincoln Mills, 353 U.S. 448, 455 (1957). However, this terminology is highly misleading. See generally Lynd, supra note 173, at 410-23. "Quid pro quo" connotes an equal exchange, but the basic tradeoff under discussion is usually dramatically skewed in management's favor for two reasons: (1) typically, the union's no-strike obligation is absolute during the term of the contract, whereas management agrees to submit its decisions to arbitral revision only with respect to "arbitrable" matters 
grievance strikes and bolster arbitration carried with it several specific theoretical and doctrinal implications. First, industrial peace emerged as the most favored "value" underlying federal labor policy. Other goals and values that the NLRA contained, 222 such as equality, industrial democracy, and self-organization, entered relative eclipse as components of the national labor policy. ${ }^{223}$ Second, it became a general principle that self-help is disfavored as a mode of industrial dispute resolution.224 Concerted activity and selforganization by workers tend no longer to be prized for their own sake, as in themselves some sort of contribution to democracy in this hierarchic and bureaucratic world. Third, a price of reconciling employers to collective bargaining was that unions undertake the role of "trustees" of industrial peace and "responsible behavior." 225

(i.e., those not retained as managerial prerogative); and (2) in the event of dispute about the meaning of the contract, management's version almost always prevails during the pendency of the arbitral process. Id. 416-23. See also F. ELkouru \& E. Elkovnr, supra note 43 , at $154-59,671$ (fundamental rule of arbitral law requires employees to obey management's allegedly improper commands while resorting to the grievance procedure). For these reasons the terms "tradeoff" and "package" have been substituted here for the traditional phrase "quid pro quo."

The postwar package included other elements, not discussed here, besides the no-strike/arbitration tradeoff. An example is the gradual acceptance of union security and the dues checkoff, despite the Taft-Hartley restrictions in this area. Also not discussed are some of the underlying assumptions of the package, such as the continued existence of an expanding economy. The postwar collective bargaining synthesis is now unraveling under pressure from both external forces (economic distress, international economic competition, and pressure from employees aggrieved by the continuing failure of the collective bargaining system adequately to address such urgent social problems as equal employment opportunity, health care, and retirement security), and internal tensions (the hierarchy and bureaucratism of the collective bargaining system, and its suppression of worker concerted activity).

222 See generally Klare, supra note 84 , at 281-85.

223 Id. 292-93; cf. Emporium Capwell Co. v. Western Addition Community Org., 420 U.S. 50,62 (1975) ("[the $\$ 7$ rights of employees] are protected not for their own sake but as an instrument of the national labor policy of minimizing industrial strife").

224 See generally Klare, supra note 3, at 452-68.

225 See, e.g., Republic Steel Corp. v. United Mine Workers, 570 F.2d 467, 479

(3d Cir. 1978):

[Unions] simply must bear certain obligations if [they are] to continue to be entitled to the rights and benefits accorded by our national labor policy. To the extent that any union ... refuses to enforce appropriately authorized union discipline upon recalcitrant members [for engaging, e.g., in wildcat strikes] . . . that union can be said to have abrogated a proportion of valued rights granted to the union under our national labor policy.

(Republic Steel held that an international union may be vicariously 'liable for damages caused by an unlawful sympathy strike of local union members, if the international fails to exhaust all reasonable means to halt the strike. This holding was effectively overruled by Carbon Fuel Co. v. United Mine Workers, 444 U.S. $212(1979)$. 
What unions had to bargain with was the promise of uninterrupted production. Both so as to avoid section 301 liability and, as a practical matter, to have something of value to sell at the bargaining table, unions found themselves saddled with major responsibility for enforcement of the no-strike clause. ${ }^{226}$

On the doctrinal level, proponents of the tradeoff had a complex message to get across. ${ }^{227}$ To begin with, they had to counter Dean Shulman's warnings ${ }^{228}$ and to pave the way for the law to "enter" the arbitral process. A preeminent, uniform source of law was needed to overcome the weaknesses of state court enforcement of collective bargaining contracts. ${ }^{229}$ A first order of business was therefore to establish section 301 as a flexible and paramount source of federal law for collective contract enforcement. This was accomplished in Lincoln Mills. ${ }^{230}$ A related task, accomplished soon thereafter, was to make the federal common law of the collective

226 It is of course true that the leading union lawyers urged the courts to buttress the arbitral system without necessarily conceding the tradeoff corollary of judicially strengthened enforcement of the no-strike obligation. Nonetheless the theories with which union lawyers elected to educate the courts, particularly the Supreme Court, did provide intellectual groundwork for both sides of the tradeoff coin, and in this sense union lawyers bear some of the responsibility for the courts' adoption of the entire package, particularly for the result in the Boys Markets injunction case, Boys Mkts. v. Retail Clerks Local 770, 398 U.S. 235 (1970). See infra notes $241-43$ and accompanying text.

227 This complexity suggests a hypothesis about why the liberal ideologues of collective bargaining, in this case most notably Justice Douglas, campaigned with such vigor to establish the principle that $\$ 301$ authorizes the federal courts to develop and promulgate a preemptive federal common law of the collective bargaining contract. See Textile Workers Union v. Lincoln Mills, 353 U.S. 448, 456-57 (1957) (Douglas, J.) ("the substantive law to apply in suits under $\S 301(\mathrm{a})$ is federal law, which the courts must fashion from the policy of our national labor laws .... The range of judicial inventiveness will be determined by the nature of the problem"). The intricacy and sophistication of the tradeoff proponents' message required that they target a relatively small, accessible group of decisionmakers, susceptible to education by elite academics and other notables. The federal judiciary fit this role nicely, much better than Congress. The federal judiciary was also a particularly congenial audience for the tradeoff proponents because, unlike Congress, it could be counted on to undercut the Norris-LaGuardia Act by a process of creating exceptions to it. See infra text accompanying notes 240-42. That Justice Frankfurter understood this, see generally F. FrankForter \& N. GREene, supra note 146, probably contributed to the bitterness of his dissent in Lincoln Mills, 353 U.S. at 460 (Frankfurter, J., dissenting).

228 See supra text accompanying note 214.

229 Some of the weaknesses of state court enforcement had to do with procedural matters (e.g., whether or not a union could be sued as an entity) that were dealt with in section 301 itself. See, e.g., 29 U.S.C. $\$ 185$ (b) (1976) (union may be sued as an entity). However, many substantive problems requiring judge-made solutions remained. For example, in some states-including Alabama, where Lincoln Mills arose-executory agreements to arbitrate disputes were not specifically enforceable. See generally Cox, supra note 148, at 247-48.

230 Textile Workers Union v. Lincoln Mills, 353 U.S. 448 (I957) (Douglas, J.). 
contract preemptive for choice-of-law purposes, ${ }^{231}$ while holding the state courts available for the job of contract enforcement. ${ }^{232}$

A second problem for tradeoff proponents was to ensure that when the law "came in," it did so only to the limited extent necessary. In particular, judicial intervention in aid of arbitration would be counterproductive unless it were as unobtrusive and deferential as possible to the autonomy of arbitration. The key theme, repeated over and over again, was that the judicial and arbitral processes ought to be mutually reinforcing: "[In contrast to Dean Shulman, others] have urged that both the institutions of self-government proliferated by collective bargaining and the surrounding legal system can gain strength from mutual support provided ... that the law achieves a workable division of authority between the arbitration and the courts." 233

To the end of achieving a "workable division of authority," proponents of the tradeoff were obliged simultaneously to argue that the arbitral system needed the assistance of the courts and that arbitration was so unique a method of conflict resolution that the courts ought not get involved in its routine operation. Ironically, in supporting this second branch of their argument, advocates turned to precisely those special features of arbitration that Shulman and others had identified in counseling that the law "stay out." They produced a burgeoning literature on the uniqueness of arbitration: its frequent reference to past practice and other extra-documentary sources of norms; its on-going role in maintäin-

231 See Local 174, Teamsters v. Lucas Flour Co., 369 U.S. 95, 102 (1962) ("incompatible doctrines of local law must give way to principles of federal labor law" in $\$ 301$ cases).

232 Charles Dowd Box Co. v. Courtney, 368 U.S. 502 (1962) - $\$ 301$ does not disturb the pre-existing jurisdiction of the state courts to enforce collective bargaining contracts).

233 Cox, supra note 148, at 247; cf. Cox, Rights Under a Labor Agreement, 69 HARv. L. REv. 601, 604-05 (1956) ("Both the new institutions of industrial self-government and the surrounding legal system can gain strength from mutual support. Labor, management, and arbitrators must recognize that the ideals and needs of society limit their freedom of decision; but the accommodation also requires infusing labor law with many of the ideas and conventions, unknown to the law but appropriate to group action, which have gained ancceptance in the world of labor relations.") (citation omitted); Cox, The Place of Law in Labor Arbitration, in The Profession of Labor Afbitration: Selected Papers from the First Seven Annual Meetings of the Natronal Agademy of Arbitrations 1948-1954, at 76,78 (J. McKelvey ed. 1957) ("The attitude of both courts and agencies towards the growing jurisprudence of labor arbitration will be deeply influenced by the attitude of arbitrators towards the law. Each can best secure respect for its appropriate jurisdiction by recognizing the proper role of the other.")

Professor Cox's theory of the "mutually supportive" role of courts and arbitrators represents an important application of the then-flourishing theory of "institutional competencies." See generally H. HART \& A. Sacks, The Legar Prociess (tent. ed. 1958). 
ing the production - process (as opposed merely to case-by-case dispute settlement); its remedial latitude and ingenuity; its informality; its cathartic functions; its involvement of lay people; and so on..$^{234}$ The key to the uniqueness of arbitration, according to this view, is that it is not just a dispute-resolution process: it is an aspect of the system of industrial governance, of the management process. ${ }^{235}$. It was therefore a crucial proviso of the "law/arbitration mutual support" idea that the judiciary be instructed on the highest authority that "legal rights and duties under a collective bargaining agreement are not imposed by conventional legal rules but are drawn out of the institutions of the industrial relations and shaped to their needs." 230 This instruction was eventually delivered in the Steelworkers Trilogy. ${ }^{237}$

A third problem for tradeoff proponents was presented by the Norris-LaGuardia Act. ${ }^{238}$ Norris-LaGuardia stands for the proposition that even if certain conduct is improper (for instance, a strike in violation of a contract), federal courts may not enjoin traditional kinds of worker activity, notably peaceful strikes and picketing. Needless to say, adherence to this principle threatened to obstruct the aspect of the package deal that promised employers efficient enforcement of no-strike obligations. One of the boldest strokes of the tradeoff proponents was, therefore, to declare the Norris-LaGuardia Act obsolete. ${ }^{239}$ To its enormous credit the Supreme Court balked at this one, at least at first. ${ }^{240}$ Eventually the Court obliged in the watershed Boys Markets case, ${ }^{241}$ holding that Norris-LaGuardia does not bar injunctions against strikes over arbitrable grievances when the collective bargaining contract at issue contains a no-strike

234 See generally Cox, Reflections upon Labor Arbitration, 72 HARv. L. Rev. 1482 ( 1959 ).

235 See generally Feller, supra note 206, at 718-71 (usefulness of grievance arbitration to management).

236 Cox, supra note 148 , at 247.

237 United Steelworkers v. Enterprise Wheel \& Car Corp., 363 U.S. 593 (1960) (Douglas, J.) (judicial deference to arbitration); United Steelworkers v. Warrior \& Gulf Navigation Co., 363 U.S. 574 (1960) (Douglas, J.) (same); United Steelworkers v. American Mfg. Co., 363 U.S. 564 (1960) (Douglas, J.) (same).

23829 U.S.C. $\$ \$ 101-115$ (1976).

239 See Cox, supra note 148, at 254 ("[t]o an undefined extent the NorrisLaGuardia Act has become an anachronism").

240 Sinclair Ref. Co. v. Atkinson, 370 U.S. 195 (1962) ( $\$ 301$ does not impliedly repeal Norris-LaGuardia Act prohibition on injunctions against peaceful strikes).

241 Boys Mkts. v. Retail Clerks Local 770, 398 U.S. 235 (1970) ( 301 partially repeals Norris-LaGuardia Act anti-injunction prohibitions by implication; strikes over arbitrable grievances in violation of contractual no-strike clauses may be enjoined by federal courts). 
clause and a mandatory arbitration procedure. This decision completed the package by, in effect, partially repealing the NorrisLaGuardia Act.

Many labor union lawyers accept Boys Markets, however.reluctantly, as a necessary consequence of a labor law regime that protects many valuable rights of unions and employees. Others, the author of this Article included, regard the decision as a profound betrayal of the promise of New Deal labor law reform. Either way, Boys Markets undoubtedly represents the triumph of liberal postwar collective bargaining theory. ${ }^{242}$ Moreover, it embodies the supreme irony of an appeal to public necessity and the reintroduction of an historically much reviled form of public intervention, all in the name of nurturing the parties' private disputeresolution system. It is consistent with the logic of a system that executes national labor policy by elevating private contractual rights over the statutory, public law rights of employees. ${ }^{243}$

Perhaps the story of the postwar tradeoff encapsulates some old Legal Realist lessons, namely that "private ordering" presupposes that public power has established a regime of rules and enforcement agencies, that the "unregulated" market is a fiction, and that private ordering is itself a mode of public regulation. The saga of Boys Markets is eloquent testimony to the proposition that no private ordering system is autonomous, or, to put it another way, that the notion of a public/private distinction is incoherent. Boys Markets teaches that the very idea of "autonomy," in this and other contexts, must be reformulated in a way that transcends the public/private dichotomy.

\section{The Ideological functions of Public/Private RHETORIC IN LABOR LAW}

Legal thought within the liberal tradition is caught in a dilemma. On the one hand, work in this mode appears incapable

242 This point is developed in Klare, supra note 180, at 47-54. Cf. Feller, supra note 206, at $714 \mathrm{n} .252$ ("[t]he result in Boys Market [sic] was in a very real sense a consequence of Lincoln Mills and the [Steelworkers] trilogy").

243 See supra text accompanying notes $212-16$. Note that $\$ 7$ rights to engage in concerted activity are rights of employees, not unions. See 29 U.S.C. $\$ 157$ (1976). Unions are empowered to "waive" employees" rights to concerted activity by granting the employer a contractual no-strike clause. See NLRB v. Sands Mfg. Co., 306 U.S. 332 (1939) (strike in breach of contractual no-strike clause is unprotected under $\$ 7$ ). Sands $M$ fg. is venerable precedent for the proposition mentioned, although the contract at issue in that case did not contain a no-strike clause. The law does not require unions to obtain employee ratification of contracts, although union constitutional provisions or bylaws requiring ratification may be legally enforceable. 
of jettisoning the intellectual apparatus associated with the public/ private distinction and several similar contrasts, such as those between group and individual, form and substance, thought and conduct, state and civil society, and so on. ${ }^{244}$ This series of conceptual categories is invested with powerful ideological significance. On the other hand, the effort to construct a vision of social life with these-categories is constantly threatened by the eroding power of experience, which perversely refuses to be cabined within this framework. ${ }^{245}$

The typical liberal response to this dilemma is ever-renewed effort to refract the complexities of social life through the basic conceptual prism comprising the set of fundamental dualities like public/private. To a significant degree liberal legal discourse has become an intellectual practice designed to generate images of the world conducing to a belief that one can meaningfully conceive of the realm of social and economic intercourse apart from the realm of politics. The endeavor to preserve the ideological power of the basic distinctions, even though every attempt to think about the world in such categories threatens to explode them, has generated many strained and contorted formulations. It has also, however, yielded some surprisingly imaginative and subtle recastings. The treatment of public and private in modern collective bargaining theory is an example of the latter kind. ${ }^{246}$

244 Cf. Frug, supra note 32 , at 1075 ("Liberalism is not a single formula for interpreting the world; it is, instead, a view based on seeing the world as a series of complex dualities"). (mentioning reason/desire, fact/value, freedom/necessity, self/community, civil society/state, and empirical fact/ideas).

245 The courts occasionally acknowledge that the public/private distinction is problematical as a description of modern social life. See, e.g., Flagg Bros. v. Brooks, 436 U.S. 149, 178 (1978) (Stevens, J., dissenting) ("it is no longer possible, if it ever was, to believe that a sharp line can be drawn between private and public actions") (footnotes omitted); see also Curtis Publishing Co. v. Butts, 388 U.S. 130, 163 (1967) (Warren, C.J., concurring):

Increasingly in this country, the distinctions between governmental and private sectors are blurred. Since the depression of the 1930's and World War II there has been a rapid fusion of economic and political power, a merging of science, industry, and government, and a high degree of interaction between the intellectual, governmental, and business worlds. . . . While these trends and events have occasioned a consolidation of governmental power, power has also become much more organized in what we have commonly considered to be the private sector. In many situations, policy determinations which traditionally were channeled through formal political institutions are now originated and implemented through a complex array of boards, committees, commissions, corporations, and associations, some only loosely connected with the Government.

.. 246 Collective bargaining theory is all the more remarkable because it has contended with the fact that the practice of collective bargaining poses serious problems for our ordinary ways of thinking about the public/private distinction. A crucial development in twentieth century American life has been the expansion and 
The essence of the public/private distinction is the conviction that it is possible to conceive of social and economic life apart from government and law, indeed that it is impossible or dangerous 'to conceive of it any other way. The core ideological function served by the public/private distinction is to deny that the practices comprising the private sphere of life-the worlds of business, education and culture, the community, and the family-are inextricably linked to and at least partially constituted by politics and law.247 Denying the role of politics-the processes by which communities organize and institutionalize their self-directive capacities-in constituting the forms and structure of social life is a way of impeding access to an understanding of the role of human agency in constructing the world. The primary effect of the public/private distinction is thus to inhibit the perception that the institutions in which we live are the product of human design and can therefore be changed. ${ }^{248}$

In the labor context, the paradigmatic form of this sort of conceptual repression is the belief that employees lack the capacity collectively to organize and govern complex industrial enterprises. The fundamental tenet of democratic politics, that human communities are capable of fashioning appropriate institutions for guiding their destinies, is not applied in the American workplace. Rather, participants in the community of work must be made to believe that industry and commerce can only function on a largely authoritarian basis, and the public/private distinction is used to explain why the basic principles of democracy do not apply in the workplace. The distinction is also used to induce consent to hierarchy by disguising it and by fostering the appearance of employee participation.

An example combining both roles of the public/private distinction is the central premise of collective bargaining theory that

primacy of corporate entities whose inteinal procedures and external contractual relationships constitute a species of lawmaking. This has involved the rise of rights-holding and power-wielding entities intermediate between government and the individual, that is, between "public" and "private" as traditionally conceived. See Frug, supra note 32, at 1128-41. See generally Jaffe, supra note 136; Kessler, supra note 136. Collective bargaining between big capital and big labor is a paradigmatic expression of the phenomenon of lawmaking by private groups.

247 This theme is pursued in Klare, Law-Making as Praxis, Telos, Summer 1979 , at $123-35$.

248 For further discussion see Frug, supra note 32, at 1074-80. See also id. 1121 (liberal "ideas have organized people's perception of the world and therefore their perception of which goals have been possible and desirable to achieve. In this way, they have influenced people's actions and, thereby, limited [their] institutional possibilities"); Gordon, Historicism in Legal Scholarship, 90 YAIE L.J. 1017 (1981); Kennedy, Cost-Reduction Theory as Legitimation, 90 YALE L.J. 1275 (1981). 
the industrial rule of law is the "autonomous" creation of labor and management. This proposition suggests that democratic political processes ought not to meddle in industrial relations and should leave existing economic hierarchies in place. It denies the crucial role of public law in establishing and protecting the "autonomous" industrial rule of law. The "autonomy" formula also implies, however, that through unions employees have already participated in constructing the industrial status quo, a point that is all the more convincing because it contains an-important element of truth. On the other hand, the formulation also legitimates existing arrangements and deflects scrutiny from the question whether they can or should be altered so as to increase employee control over the institutions that dominate their working lives.

The thesis of this Article is that the public/private distinction is continuously invoked; refined; and reformulated in labor law in connection with the effort to induce the belief that workers should be denied power and participation in industrial life. In particular, public/private thinking has significant implications for three issues: popular control of investment decisions; worker control of the labor process; and the place of the individual in union governance.

\section{A. Social Control of Private Power: Worker Control of Investment Decisions}

Those seeking to impose the democratic norms of participation, fairness, communal responsibility, and respect for the individual upon those exercising social and economic power would have an easier battle if the starting point of discussion were that there is no such thing as "private" power because government is implicated in and partially responsible for the prevailing structure of wealth and domination. ${ }^{249}$ The public/private distinction conveys the impression that the social structure of domination is natural, at least insofar as it was "there first," "before" the actions of government, and it thereby impedes the moral imagination. It makes it more difficult for us to conceive of a world in which it is deemed unacceptable to exercise power over others unconstrained by participatory norms, regard for the community, and respect for the dignity of the individual. The most important example of this problem in the labor law context is the mobilization of public/private rhetoric to justify employer control of investment and resource-allocation de-

$249 \mathrm{Cf}$. Cohen, Property and Sovereignty, 13 ConNel, L.Q. 8 (1927) (early statement of view that law is factor in structuring the distribution of economic power). 
cisions of societal consequence-in a word, to justify private ownership of the means of production. ${ }^{250}$

\section{B. Participation and Self-Governance: Warker Control of the Labor Process}

By positing a "private" domain of life that is not presumptively' constrained by democratic norms, the public/private dichotomy. induces us to think of the promise of freedom as residing only in the part of life that is presumptively amenable to collective selfregulation, the polity. This in turn induces us to conceive of freedom in a singular manner-as a particular relationship to state power. That is, public/private rhetoric tends to channel democratic aspirations into the framework of individualistic rights theory.

Public/private rhetoric thereby inhibits us from embracing alternative conceptions, such as the view that freedom is in part the development of the capacity for communal self-governance across the entire existential space of life. The potential and need to participate in organizing the social world and guiding its future is a generic human capacity. The nature of our species embraces the aspiration toward collective self-governance, and our attainment of it is a measure of our freedom. The public/private distinction diminishes the potential for enhancing our capacities of self-governance, not only in the workplace, but in the family, the neighborhood, and the polity. In the labor law context, public/ private rhetoric supports a spectrum of doctrines designed to deny worker participation in enterprise governance and to deny that the workplace can be for employees a locus of personal and collective realization, growth, and expression. ${ }^{\mathbf{5} 1}$

\section{G. Autonomy and Community: The Individual Employee and Union Solidarity}

Public/private rhetoric conduces to the belief that the individual and the community are radically distinct and antagonistic. This way of thinking suppresses the truth that in significant measure we are the ensemble of our social relations and shared meanings; and that our individuality is in many. ways defined in relationship to our shared meanings and symbols. Human fulfillment is impossible outside of and apart from communal life. Yet public/ private rhetoric teaches that community is necessarily a threat: to

250 See supra notés 191-94 and accompanying text.

251 See, e.g., supra notes $16-22,46,48,75-77 \& 123-27$ and accompanying text. See generally Klare, supra note 180 . 
autonomy, that liberty and equality are necessarily at odds. That is, public/private rhetoric inhibits us from regarding self-governed group life as a wellspring of personal growth and fulfillment.

The liberal tradition and its derivative, predominantly individualistic theories of legal rights almost universally deny the possibility that group life as an end in itself might be enriching for the individual: ${ }^{252}$ This denial places all groups or institutions intermediate between the state and individual, such as unions, universities, and cities, in a precarious theoretical position, and poses an intractable dilemma for liberal politics. This dilemma is deftly articulated by Professsor Frug:

$[I] t$ is a paradox that while liberalism can be understood as an attempt to eradicate group power in favor of that of the individual and the state, most liberal thinkers seem convinced that the creation of a world without any intermediate bodies-a world in which the state is the only power wielder other than individuals themselves-would leave individuals powerless to prevent a centralized state from threatening their liberty. . . .

... The exercise of state power infringes individual rights protected by independent corporations, yet the exercise of corporate power infringes individual rights protected by the state. Every time we seek state help to protect us from a corporate invasion of our rights, we strengthen one threat to our liberty at the expense of another; yet every time we prevent the state from protecting us against corporate power, we accomplish the same result

... Independent group power is simply not an idea, whether clothed in the name of rights or sovereignty, that can be defended within a liberal legal system against liberal attack..$^{253}$

This framework effectively disallows the possibility that the individual's potential for self-realization can be enhanced by strengthen-

252 The guarantee in NLRA $\$ 7,29$ U.S.C. $\$ 157$ (1976) of the right of employees to "concerted activities for the purpose of collective bargaining or other mutual aid or protection" is perhaps the most important exception to this generalization in American law. See generally Lynd, supra note 3, at 494-95. No doubt this is why $\$ 7$ is so brutally disfavored in judicial and administrative interpretation. See supra notes 196-97.

253 Frug, supra note 32, at 1122-25 (footnotes omitted). 
ing group solidarity, and it thereby precludes alternative visions of freedom. This point has two ramifications in the labor?law context. The first is that liberal collective bargaining law makes it seem implausible that the union can function as a. locus of group life and public discourse. ${ }^{254}$ Union activity is conceived primarily in instrumental terms, not as a collective experience for employees in the emancipatory project of becoming the authors.of their own destinies. This reinforces all the other pressures in the political culture that breed hierarchical and apolitical unions concerned about a narrow range of economic issues. ${ }^{255}$ Second, with some important exceptions, the public/private distinction imposes an intolerable choice in the context of most union democracy litigation. That choice is between allowing unions and dissenting employees to harm one another and permitting the government to intrude into union affairs as a byproduct of preventing such harm. In contemporary employee-union litigation, workers often look to state intervention to protect them from abuses of union power, ${ }^{256}$ while unions simultaneously look to the state for protection-from the fragmenting effects of individual employee dissent. ${ }^{257}$. The problems of the duty of fair representation, members' speech and election rights, and union security cannot be satisfactorily resolved, however, unless we can articulate and gain acceptance for a new conception of worker participation in unions as fulfillment through collective, self-governed experience. ${ }^{258}$

\section{GONCLUSION}

This Article is informed by a belief in the possibility and desirability of a mode of self-governed group life that is an alternative to liberal democratic theories that fracture social life between public and private domains. Such theories do not fully account for the social context of human experience and therefore cannot adequately appreciate the social determinants of human freedom.

254 Some exceptions to this claim are noted in Klare, supra note 3 , at 472 and 472 n.81.

255 For discussion of legal doctrines tending to reinforce unions' apolitical stance, see supra notes 72-79, 184-85 \& 191-93 and accompanying text. See generally Cloke, Political Loyalty, Labor Democracy and the Constitution, 5 SAN FERN. V.L. REv. 159 (1976) (role of law in fostering apolitical unions).

256 See, e.g., supra notes 51-58 and accompanying text.

257 See, e.g., supra notes $62-63$ \& 69-74 and accompanying text.

258 Cf. NLRB v. Granite State Joint Bd., 409 U.S. 213, 221 (1972) (Blackmun, J., dissenting) (" $[u]$ nion activity ... . is group activity, and is grounded on the notion that strength can be gamered from unity, solidarity, and mutual commitment"). 
The alternative conception of democracy values communal experience and responsibility more highly than does the individualism so pronounced in the liberal tradition. It is a mistake, however, to view this alternative theory as seeking to "strengthen the community at the expense of the individual," as some might charge. The theory aspires to enhance both individual autonomy and communal solidarity, thereby displacing the inherent conflict between individualism and collective control that informs the liberal perspective-and that corresponds to the public/private distinction. The vision of solidarity advanced here $i$ a vision of autonomy, of a form of social life that nurtures the capacity of every individual to experience self-realization. ${ }^{259}$

259 See H. MARcuse, AN EsSay on Limeration 88 (1969):

[S]elf-determination begins at home-and that is with every $I$, and the We whom the $I$ chooses. And this end must indeed appear in the means to attain it, that is to say, in the strategy of those who, within the existing society, work for the new one .... Exploitation in all its forms must have disappeared from this fight: from the work relationships among the fighters as well as from their individual relationships. Understanding, tenderness toward each other, the instinctual consciousness of that which is evil, false, the heritage of oppression, would then testify to the authenticity of the rebellion. 